\title{
ACC/AATS/AHA/ASE/ASNC/SCAI/SCCT/STS 2017 appropriate use criteria for coronary revascularization in patients with stable ischemic heart disease
}

A report of the American College of Cardiology Appropriate Use Criteria Task Force, American Association for Thoracic Surgery, American Heart Association, American Society of Echocardiography, American Society of Nuclear Cardiology, Society for Cardiovascular Angiography and Interventions, Society of Cardiovascular Computed Tomography, and Society of Thoracic Surgeons

\section{Coronary}

Revascularization Writing Group:

\section{Rating Panel:}

Appropriate Use Criteria Task Force:
Manesh R. Patel, MD, FACC, FAHA, FSCAI, Chair, John H. Calhoon, MD,

Gregory J. Dehmer, MD, MACC, MSCAI, FAHA, ${ }^{a}$ James Aaron Grantham, MD, FACC, Thomas M. Maddox, MD, MSc, FACC, FAHA, David J. Maron, MD, FACC, FAHA, and Peter K. Smith, MD, FACC ${ }^{b}$

Michael J. Wolk, MD, MACC, Moderator,

Manesh R. Patel, MD, FACC, FAHA, FSCAI, Writing Group Liaison,

Gregory J. Dehmer, MD, MACC, FSCAI, FAHA, Writing Group Liaison ${ }^{\mathrm{a}}$

Peter K. Smith, MD, FACC, Writing Group Liaison,

James C. Blankenship, MD, MACC, MSCAI, ${ }^{c}$ Alfred A. Bove, MD, PhD, MACC,

Steven M. Bradley, MD, ${ }^{\mathrm{d}}$ Larry S. Dean, MD, FACC, FSCAI, ${ }^{2}$

Peter L. Duffy, MD, FACC, FSCAI, ${ }^{\text {a }}$ T. Bruce Ferguson, Jr, MD, FACC,

Frederick L. Grover, MD, FACC ${ }^{\mathrm{c}}$ Robert A. Guyton, MD, FACC,

Mark A. Hlatky, MD, FACC, ${ }^{\mathrm{c}}$ Harold L. Lazar, MD, FACC, ${ }^{\mathrm{f}}$ Vera H. Rigolin, MD, FACC, ${ }^{\mathrm{c}}$

Geoffrey A. Rose, MD, FACC, FASE, ${ }^{g}$ Richard J. Shemin, MD, FACC,

Jacqueline E. Tamis-Holland, MD, FACC ${ }^{\text {c }}$ Carl L. Tommaso, MD, FACC, FSCAI,

L. Samuel Wann, MD, MACC, ${ }^{\mathrm{h}}$ and John B. Wong, MD

John U. Doherty, MD, FACC, Co-Chair, Gregory J. Dehmer, MD, MACC, Co-Chair,

Steven R. Bailey, MD, FACC, FSCAI, FAHA, Nicole M. Bhave, MD, FACC,

Alan S. Brown, MD, FACC, Stacie L. Daugherty, MD, FACC,

Milind Y. Desai, MBBS, FACC, Claire S. Duvernoy, MD, FACC,

Linda D. Gillam, MD, FACC, Robert C. Hendel, MD, FACC, FAHA,

Christopher M. Kramer, MD, FACC, FAHA, ${ }^{j}$ Bruce D. Lindsay, MD, FACC,

Warren J. Manning, MD, FACC, Manesh R. Patel, MD, FACC, FAHA, ${ }^{k}$

Ritu Sachdeva, MBBS, FACC, L. Samuel Wann, MD, MACC,

David E. Winchester, MD, FACC, Michael J. Wolk, MD, MACC, ${ }^{i}$ and Joseph M. Allen, MA

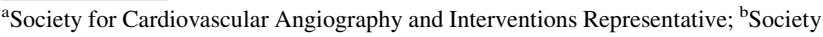
of Thoracic Surgeons Representative; 'American College of Cardiology Representative; ${ }^{\mathrm{d}}$ American Heart Association Representative; ${ }^{\mathrm{e}}$ Society of Thoracic Surgeons Representative; ${ }^{\mathrm{f}}$ American Association for Thoracic Surgery Representative; ${ }^{\mathrm{g}}$ American Society of Echocardiography Representative; ${ }^{\mathrm{h}}$ American Society of Nuclear Cardiology Representative; ${ }^{i}$ Former Task Force member, current member during the writing effort; ${ }^{j}$ Former Task Force Co-Chair, current Co-Chair during the writing effort; ${ }^{\mathrm{k}}$ Former Task Force Chair, current Chair during the writing effort.

This document was approved by the American College of Cardiology Clinical Policy Approval Committee on behalf of the Board of Trustees in January 2017.

The American College of Cardiology requests that this document be cited as follows: Patel MR, Calhoon JH, Dehmer GJ, Grantham JA, Maddox TM, Maron DJ, Smith PK. ACC/AATS/AHA/ASE/ASNC/SCAI/SCCT/STS 2017 appropriate use criteria for coronary revascularization in patients with stable ischemic heart disease: a report of the American College of Cardiology Appropriate Use Criteria Task Force, American Association for Thoracic Surgery, American Heart Association, American Society of Echocardiography, American Society of Nuclear
}

Cardiology, Society for Cardiovascular Angiography and Interventions, Society of Cardiovascular Computed Tomography, and Society of Thoracic Surgeons. J Am Coll Cardiol. 2017;69:2212-41.

This document is reprinted with the permission of the American College of Cardiology Foundation.

Copies: This document is available on the World Wide Web site of the American College of Cardiology (www.acc.org). For copies of this document, please contact Elsevier Reprint Department, fax (212) 633-3820 or e-mail reprints@ elsevier.com. Permissions: Multiple copies, modification, alteration, enhancement, and/or distribution of this document are not permitted without the express permission of the American College of Cardiology. Requests may be completed online via the Elsevier site (http://www.elsevier.com/about/policies/author-agreement/obtainingpermission).

DOI of original article: https://doi.org/10.1016/j.jtcvs.2017.05.029

J Thorac Cardiovasc Surg 2019;157:e131-61

$0022-5223 / \$ 36.00$

(C) 2017 by the American College of Cardiology Foundation. Published by Elsevier. https://doi.org/10.1016/j.jtcvs.2018.11.027 
See Commentary on page 144 in the January 2019 issue.

\section{TABLE OF CONTENTS}

Abstract. . . . . . . . . . . . . . . . e132

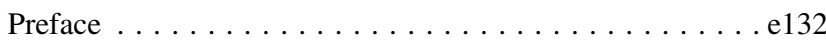

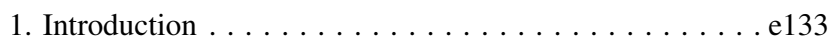

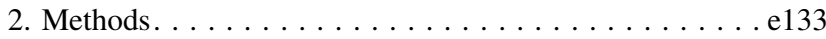

Indication Development . . . . . . . . . . . . . . . . . . . . 133

Appropriate Use Definition and Ratings. . . . . . . . . . . . e134

Median Score 7 to 9: Appropriate Care . . . . . . . . . . . e134

Median Score 4 to 6: May Be Appropriate Care. . . . . . . .e134

Median Score 1 to 3: Rarely Appropriate Care . . . . . . . .e134

Scope of Indications . . . . . . . . . . . . . . . . . . . . . . . . . . . . . . . . . . . . . . . .

3. Assumptions. . . . . . . . . . . . . . . . e135

General Assumptions. . . . . . . . . . . . . . . e135

Assumptions for Rating Multiple Treatment Options . . . . e137

4. Definitions . . . . . . . . . . . . . . . . . . e137

Indication. . . . . . . . . . . . . . . . . . e137

Risk Factor Modification (Secondary Prevention) and

Antianginal Medical Therapy . . . . . . . . . . . . . .e137

Stress Testing and Risk of Findings on Noninvasive Testing . . .e137

Vessel Disease . . . . . . . . . . . . . . . . . . . . . . . . . . . . . . 137

Ischemic Symptoms. . . . . . . . . . . . . . . . . . .e138

Invasive Methods of Determining Hemodynamic Significance .e138

The Role of Patient Preference in the AUC . . . . . . . . e138

5. Abbreviations . . . . . . . . . . . . . . . . e140

6. Coronary Revascularization in Patients With Stable

Ischemic Heart Disease: Appropriate Use Criteria

(By Indication) . . . . . . . . . . . . . . . . . . . . . e140

Section 1. SIHD Without Prior CABG. . . . . . . . . . . . e140

Table 1.1. One-vessel disease . . . . . . . . . . . e141

Table 1.2. Two-vessel disease . . . . . . . . . . . e e141

Table 1.3. Three-vessel disease . . . . . . . . . . . e141

Table 1.4. Left main coronary artery stenosis . . e e141

Section 2. Tables 2.1 and 2.2 SIHD With Prior CABG . . .e142

Section 3. Table 3.1 SIHD Undergoing Procedures for Which

Coronary Revascularization May Be Considered. . . . . . . . . .e143

7. Discussion . . . . . . . . . . . . . . . . . . e144

Application of Criteria. . . . . . . . . . . . . . . . . . . . . . . . . . . .

ACC President and Staff . . . . . . . . . . . . . . . . e148

References . . . . . . . . . . . . . . . . . . . . . . e 148

Appendix A ACC/AATS/AHA/ASE/ASNC/SCAI/SCCT/

STS 2017 Appropriate Use Criteria for

Coronary Revascularization in Patients With

Stable Ischemic Heart Disease: Participants . . e150

Appendix B Relationships With Industry and Other

Entities ................. e152

\section{ABSTRACT}

The American College of Cardiology, Society for Cardiovascular Angiography and Interventions, Society of Thoracic Surgeons, and American Association for Thoracic Surgery, along with key specialty and subspecialty societies, have completed a 2-part revision of the appropriate use criteria (AUC) for coronary revascularization. In prior coronary revascularization AUC documents, indications for revascularization in acute coronary syndromes and stable ischemic heart disease (SIHD) were combined into 1 document. To address the expanding clinical indications for coronary revascularization, and to align the subject matter with the most current American College of Cardiology/American Heart Association guidelines, the new AUC for coronary artery revascularization were separated into 2 documents addressing SIHD and acute coronary syndromes individually. This document presents the AUC for SIHD.

Clinical scenarios were developed to mimic patient presentations encountered in everyday practice. These scenarios included information on symptom status; risk level as assessed by noninvasive testing; coronary disease burden; and, in some scenarios, fractional flow reserve testing, presence or absence of diabetes, and SYNTAX score. This update provides a reassessment of clinical scenarios that the writing group felt were affected by significant changes in the medical literature or gaps from prior criteria. The methodology used in this update is similar to the initial document but employs the recent modifications in the methods for developing AUC, most notably, alterations in the nomenclature for appropriate use categorization.

A separate, independent rating panel scored the clinical scenarios on a scale of 1 to 9 . Scores of 7 to 9 indicate that revascularization is considered appropriate for the clinical scenario presented. Scores of 1 to 3 indicate that revascularization is considered rarely appropriate for the clinical scenario, whereas scores in the mid-range of 4 to 6 indicate that coronary revascularization may be appropriate for the clinical scenario.

As seen with the prior coronary revascularization AUC, revascularization in clinical scenarios with high symptom burden, high-risk features, and high coronary disease burden, as well as in patients receiving antianginal therapy, are deemed appropriate. Additionally, scenarios assessing the appropriateness of revascularization before kidney transplantation or transcatheter valve therapy are now rated. The primary objective of the AUC is to provide a framework for the assessment of practice patterns that will hopefully improve physician decision making.

\section{PREFACE}

The American College of Cardiology (ACC), in collaboration with the Society for Cardiovascular Angiography and Interventions, Society of Thoracic Surgeons, American Association for Thoracic Surgery, and other societies, developed and published the first version of the AUC for 
coronary revascularization in 2009 , releasing the last update in 2012. The AUC are an effort to assist clinicians in the rational use of coronary revascularization in common clinical scenarios found in everyday practice. The new AUC for coronary revascularization were developed as separate documents for stable ischemic heart disease (SIHD) and acute coronary syndromes. This was done to address the expanding clinical indications for coronary revascularization, include new literature published since the last update, and align the subject matter with the ACC/American Heart Association guidelines. An additional goal was to address several of the shortcomings of the initial document that became evident as experience with the use of the AUC accumulated in clinical practice.

The publication of AUC reflects 1 of several ongoing efforts by the ACC and its partners to assist clinicians who are caring for patients with cardiovascular diseases and to support high-quality cardiovascular care. The ACC/American Heart Association clinical practice guidelines provide a foundation for summarizing evidence-based cardiovascular care and, when evidence is lacking, provide expert consensus opinion that is approved in review by the ACC and American Heart Association. However, in many areas, variability remains in the use of cardiovascular procedures, raising questions of over- or underuse. The AUC provide a practical standard upon which to assess and better understand variability.

We are grateful to the writing committee for the development of the overall structure of the document and clinical scenarios and to the rating panel-a professional group with a wide range of skills and insights-for their thoughtful deliberation on the merits of coronary revascularization for various clinical scenarios. We would also like to thank the parent AUC Task Force and the ACC staff-Joseph Allen, Leah White, and specifically, Maria Velasquez-for their skilled support in the generation of this document.

Manesh R. Patel, MD, FACC, FAHA, FSCAI Chair, Coronary Revascularization Writing Group Immediate Past Chair Appropriate Use Criteria Task Force Michael J. Wolk, MD, MACC, Moderator Appropriate Use Criteria Task Force

\section{INTRODUCTION}

In a continuing effort to provide information to patients, physicians, and policy makers, the Appropriate Use Task Force approved this revision of the 2012 Coronary Revascularization AUC. ${ }^{1}$ Since publication of the 2012 AUC focused update, the original nomenclature used to characterize appropriate use has changed. ${ }^{2}$ New clinical practice guidelines (CPGs) for SIHD have been released, and new clinical trials extending the knowledge and evidence around coronary revascularization have been published. ${ }^{3,4}$ These trials include studies not only on the use of percutaneous coronary intervention (PCI), but also on coronary artery bypass graft surgery $(\mathrm{CABG})$, medical therapy, and diagnostic technologies such as fractional flow reserve (FFR) to guide revascularization..$^{5-8}$ Additional studies, some based on data from the National Cardiovascular Data Registry (NCDR), have been published providing insights into practice patterns and information around clinical scenarios and patient features not previously addressed. - $^{-13}$

Improvements in our understanding of the variables affecting patient outcomes before and after coronary revascularization, continued emphasis on the role of medical therapy for coronary artery disease (CAD), and an increasing emphasis on shared decision making and patient preferences also make a revision of the coronary revascularization AUC timely. ${ }^{14}$ This document focuses on SIHD and is a companion to the AUC specifically for acute coronary syndromes.

\section{METHODS}

\section{Indication Development}

A multidisciplinary writing group consisting of cardiovascular health outcomes researchers, interventional cardiologists, cardiothoracic surgeons, and general cardiologists was convened to review and revise the prior coronary revascularization AUC. The writing group was tasked with developing clinical indications (scenarios) that reflect typical situations encountered in everyday practice that were then rated by a technical panel. In this document, the term "indication" is used interchangeably with the phrase "clinical scenario." Critical data elements and mapping of the criteria to the elements will be provided for end-users of the revascularization AUC so that procedure notes and chart abstraction can be more easily mapped to the AUC. A key goal of this effort is to leverage the NCDR (National Cardiovascular Data Registry) CathPCI registry to map indications to appropriateness ratings, so that minimal additional data collection is needed to support quarterly feedback to sites of their performance as a foundation for improving patient selection for revascularization. The AUC Task Force is committed to supporting linkage of the AUC with daily workflow to capture the data elements needed for AUC ratings.

The revascularization AUC are based on our current understanding of procedure outcomes plus the potential patient benefits and risks of the revascularization strategies examined. Although the AUC are developed to address many of the common clinical scenarios encountered in practice, it would be impossible to include every conceivable patient presentation and maintain a workable document for clinicians. The writing group acknowledges that the current AUC do not evaluate all patient variables that might affect 1 or more strategies for the management of patients with CAD. Examples of conditions not explicitly considered within the scenarios include severe chronic kidney disease, severe peripheral vascular disease, known malignancies, poor lung function, advanced liver disease, advanced dementia, and/or other comorbidities that might have excluded patients from the clinical trials that provide the evidence base for coronary revascularization. Nevertheless, it is necessary for the clinician to include these conditions in the final decision-making process for an individual patient, and this may result in the actual therapy deviating from the AUC rating. It is expected that all clinicians will occasionally treat patients with extenuating conditions that are not captured in the current AUC, and this could result in a treatment rating of "rarely appropriate" for the chosen therapy in a specific patient. However, these situations should not 
constitute a majority of treatment decisions, and it is presumed that they will affect all practitioners equally, thereby minimizing substantial biases in assessing the performance of individual clinicians compared with their peers. Additionally, these AUC were developed in parallel with efforts to update data collection within the NCDR registries to include data fields that capture some of these extenuating circumstances, thereby improving the characterization of scenarios in the AUC.

AUC documents often contain specific clinical scenarios rather than the more generalized situations covered in CPGs; thus, subtle differences between these documents may exist. The treatment of patients with SIHD should always include therapies to modify risk factors and/or reduce cardiovascular events-so-called secondary prevention. In several CPGs, the phrase "guideline-directed medical therapy" is used and, depending on the context, may include the use of antianginal therapy in addition to therapies for secondary prevention. In this AUC, it is assumed that all patients will be receiving comprehensive secondary prevention therapies as needed. Antianginal therapy has a central role in the treatment of patients with SIHD. In some patients, it may be the sole therapy, whereas in others it may be continued, albeit in lower doses, following a revascularization procedure. The earlier coronary revascularization AUC included information about the intensity of antianginal therapy in several scenarios, with language such as "receiving no or minimal anti-ischemic therapy" or "receiving a course of maximal anti-ischemic therapy." The new AUC adopts a different format, including options for the initiation or escalation of antianginal therapy patterned after recommendations made in the 2012 ACCF/AHA/ACP/AATS/PCNA/SCAI/STS Guideline for the Diagnosis and Management of Patients With Stable Ischemic Heart Disease (2012 SIHD guideline), ${ }^{3}$ using a structure that mimics clinical practice. However, the primary purpose of these AUCs is to rate the appropriateness of revascularization with the understanding that decisions about revascularization are frequently made in the context of ongoing antianginal therapy. Because recommendations for revascularization or the medical management of CAD are found throughout several CPGs, the AUC ratings herein are meant to unify related CPGs and other data sources and provide a useful tool for clinicians.

These AUC were developed with the intent of assisting patients and clinicians, but they are not intended to diminish the acknowledged complexity or uncertainty of clinical decision making and should not be used as a substitute for sound clinical judgment. There are acknowledged evidence gaps in many areas where clinical judgment and experience must be blended with patient preferences and the existing knowledge base defined in CPGs. It is important to emphasize that a rating of appropriate care does not mandate that a revascularization procedure be performed; likewise, a rating of rarely appropriate care should not prevent a revascularization procedure from being performed. It is anticipated, as noted in the previous text, that there will be occasional clinical scenarios rated rarely appropriate in which performing revascularization may still be in the best interest of a particular patient. In situations in which the AUC rating is not followed, clinicians should document the specific patient features not captured in the clinical scenario or the rationale for the chosen therapy. Depending on the urgency of care, convening a heart team or obtaining a second opinion may be helpful in some of these settings.

The AUC can be used in several ways. As a clinical tool, the AUC assist clinicians in evaluating possible therapies under consideration and can help better inform patients about their therapeutic options. As an administrative and research tool, the AUC provide a means of comparing utilization patterns among providers to thereby derive an assessment of an individual clinician's management strategies compared with his/her peers. It is critical to understand that the AUC should be used to assess an overall pattern of clinical care rather than being the final arbitrator of specific individual cases. The ACC and its collaborators believe that an ongoing review of one's practice using these criteria will help guide more effective, efficient, and equitable allocation of healthcare resources, and ultimately, better patient outcomes. However, under no circumstances should the AUC be used to adjudicate or determine payment for individual patients. Rather, the intent of the AUC is to provide a framework to evaluate overall clinical practice patterns and improve the quality of care.

In developing these AUC for coronary revascularization, the rating panel was asked to rate each indication using the following definition of appropriate use:

A coronary revascularization is appropriate care when the potential benefits, in terms of survival or health outcomes (symptoms, functional status, and/or quality of life), exceed the potential negative consequences of the treatment strategy.

The rating panel scored each indication on a scale from 1 to 9 as follows:

Score 7 to 9: Appropriate care

Score 4 to 6: May be appropriate care

Score 1 to 3: Rarely appropriate care

\section{Appropriate Use Definition and Ratings}

In rating these criteria, the rating panel was asked to assess whether the use of revascularization for each indication is "appropriate care," "may be appropriate care," or is "rarely appropriate care" using the following definitions and their associated numeric ranges. Anonymized individual scores are available in an online appendix.

\section{Median Score 7 to 9: Appropriate Care}

An appropriate option for management of patients in this population, as the benefits generally outweigh the risks; an effective option for individual care plans, although not always necessary depending on physician judgment and patient-specific preferences (ie, procedure is generally acceptable and is generally reasonable for the indication).

\section{Median Score 4 to 6: May Be Appropriate Care}

At times an appropriate option for management of patients in this population due to variable evidence or agreement regarding the benefit to risk ratio, potential benefit based on practice experience in the absence of evidence, and/or variability in the population; effectiveness for individual care must be determined by a patient's physician in consultation with the patient on the basis of additional clinical variables and judgment along with patient preferences (ie, procedure may be acceptable and may be reasonable for the indication).

\section{Median Score 1 to 3: Rarely Appropriate Care}

Rarely an appropriate option for management of patients in this population due to the lack of a clear benefit/risk advantage; rarely an effective option for individual care plans; exceptions should have documentation of the clinical reasons for proceeding with this care option (ie, procedure is not generally acceptable and is not generally reasonable for the indication).

The process for development of the AUC is shown in Figure 1 and described in detail in previous documents. ${ }^{1,2}$

After completion and tabulation of the second round of ratings, it became apparent to the writing group that the original structure of certain rating tables may have confused some members of the rating panel, causing ratings that were not internally consistent. This resulted in a re-evaluation and redesign of the rating table structure, which then required a third round of ratings. This AUC document presents the end result of that process and the results of the third round of ratings.

\section{Scope of Indications}

The indications for coronary revascularization in SIHD were developed considering the following common variables: 
1. The clinical presentation (eg, low or high activity level to provoke ischemic symptoms);

2. Use of antianginal medications;

3. Results of noninvasive tests to evaluate the presence and severity of myocardial ischemia;

4. Presence of other confounding factors and comorbidities such as diabetes;

5. Extent of anatomic disease;

6. Prior coronary artery bypass surgery; and

7. Invasive testing such as intravascular ultrasound (IVUS) and invasive physiology such as FFR.

The anatomic construct for $\mathrm{CAD}$ is based on the presence or absence of flow-limiting obstructions in the coronary arteries categorized by the number of vessels involved (1-, 2-, and 3-vessel, and/or left main CAD). Additionally, we included in the anatomic construct the presence or absence of proximal left anterior descending (LAD) disease. This specific stenosis location was identified in both the $2011 \mathrm{ACCF} / \mathrm{AHA}$ guideline for coronary artery bypass graft surgery (2011 CABG guidelines) and 2012 ACC/AHA/ SCAI guideline for percutaneous coronary intervention (2012 PCI guidelines) and was included in clinical trial recruitment to guide revascularization decisions. ${ }^{6,15,16}$ Other factors such as diabetes and the complexity of disease were included in certain clinical scenarios given their effect on cardiac risk and association with more favorable outcomes from surgical revascularization. As before, noninvasive test findings are included in many scenarios to distinguish patients with a low risk for future adverse events from those with intermediate- or high-risk findings, as these terms are routinely used in clinical practice.

Antianginal treatment of $\mathrm{CAD}$ is incorporated into the structure of the tables following the pattern of recommendations in the SIHD guideline (see 2012 SIHD guidelines, Section 4.4.3.1.) but without specific drug or dose recommendations. ${ }^{3,4}$ In general, beta blockers are recommended as the initial treatment for symptom relief (Class I recommendation), with calcium channel blockers, long-acting nitrates, or ranolazine prescribed in combination with beta blockers when initial treatment with beta blockers is inadequate to control symptoms despite appropriate dosing. Calcium channel blockers, long-acting nitrates, or ranolazine should be prescribed for relief of symptoms when beta blockers are contraindicated or cause unacceptable side effects. Long-acting nondihydropyridine calcium channel blockers are reasonable alternatives to beta blockers as first-line therapy for antianginal symptoms (Class IIa, Level of Evidence: B). The use of FFR was incorporated to a greater extent than in the previous AUC as more data on the usefulness of this testing modality have emerged. Other physiologic measurements using the ratio of distal coronary to aortic pressure without hyperemia exist, and correlate with FFR, but are not as wellvalidated and lack the clinical outcomes data existing for FFR.

\section{ASSUMPTIONS}

\section{General Assumptions}

Specific assumptions provided to the rating panel for their use in rating the relevant clinical scenarios are summarized in the following text.

1. When available, each clinical scenario includes the patient's clinical status/symptom complex, ischemic burden as determined by noninvasive functional testing, burden of coronary atherosclerosis as determined by angiography, and additional invasive testing evaluations by invasive physiology (eg, FFR, or other physiological pressure measurements not requiring hyperemia) or intravascular imaging.
2. When utilized, stress testing, with or without an associated imaging procedure, was performed correctly and with sufficient quality to produce a meaningful and accurate result within the limits of the test performance. Evidence of myocardial viability is also an important finding and in some clinical situations may influence the decision for revascularization, but it was not used to further expand the number of indications.

3. As the main focus of this AUC is revascularization, assume that coronary angiography has been performed. The rating panel should judge the appropriateness of revascularization on the basis of the clinical scenario presented, including the coronary disease identified, independent of a judgment about the appropriateness of the coronary angiogram in the scenario.

4. Assume no other significant coronary artery stenoses are present except those specifically described in the clinical scenario.

5. A significant coronary stenosis for the purpose of the clinical scenarios is defined as:

- $\geq 70 \%$ luminal diameter narrowing, by visual assessment, of an epicardial stenosis measured in the "worst view" angiographic projection;

- $\geq 50 \%$ luminal diameter narrowing, by visual assessment, of a left main stenosis measured in the "worst view" angiographic projection; or

- $40 \%$ to $70 \%$ luminal narrowing, by visual assessment, of an epicardial stenosis measured in the "worst view" angiographic projection with an abnormal FFR as defined in the following text.

6. An FFR $\leq 0.80$ is abnormal and is consistent with downstream inducible ischemia. FFR is the reference standard for invasively assessing the physiological significance of a coronary artery stenosis before PCI. Newer physiological measurements that do not require hyperemia measure the ratio of distal coronary pressure to aortic pressure during the whole cardiac cycle or the wavefree portion of the cycle. Both indices have similar diagnostic concordance with FFR, but have different normal values and have not been as well-studied as FFR. Substitution of 1 of the newer physiological measurements for FFR may be considered provided the appropriate reference values are used.

7. All patients included in these scenarios are receiving needed therapies to modify existing risk factors as outlined in CPGs and other documents. ${ }^{17-19}$ Despite the best efforts of the clinician, all patients may not achieve target goals for cardiac risk factor modification. However, a continuing effort and plan of care to address risk factors are assumed to exist.

8. For patients with SIHD, the writing group recognizes there are many choices for antianginal therapy and considerable variation in the use and tolerance of 


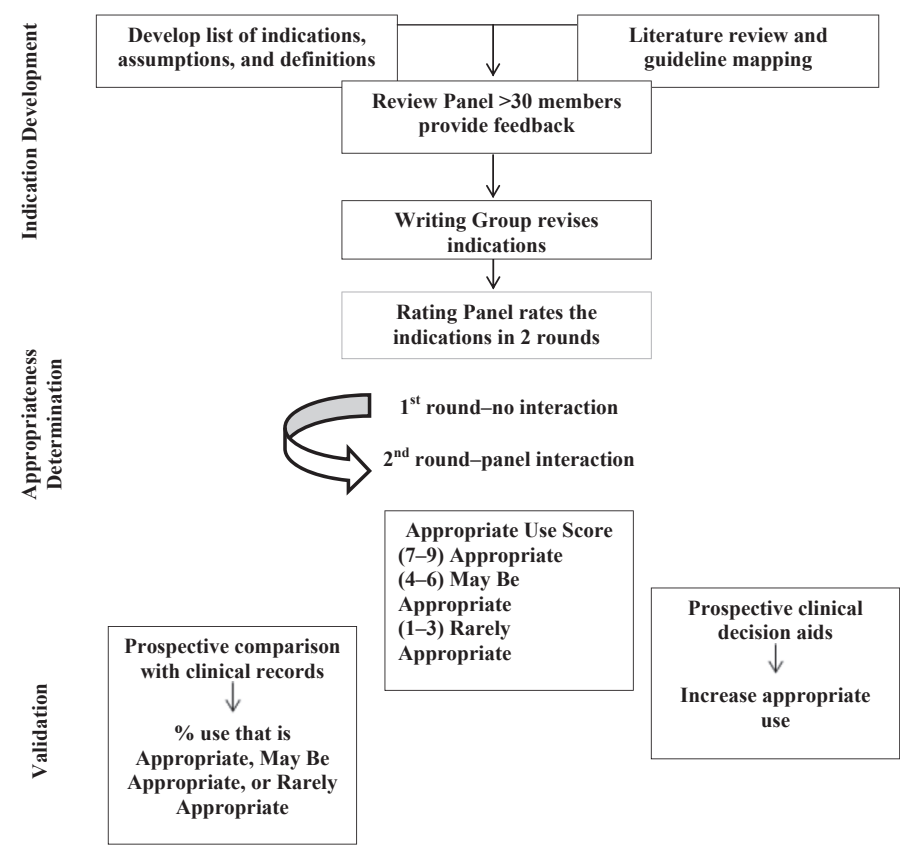

FIGURE 1. AUC development process. AUC, Appropriate use criteria.

antianginal medications among patients. The use of antianginal therapy adopted in this AUC follows the recommendations of the SIHD guideline. Assume that antianginal therapy is prescribed at a dose that adequately controls the patient's symptoms or is the maximally tolerated dose for a particular drug.

9. Operators performing percutaneous or surgical revascularization have appropriate clinical training and experience and have satisfactory outcomes as assessed by quality assurance monitoring. ${ }^{15,20,21}$

10. Revascularization by either percutaneous or surgical methods is performed in a manner consistent with established standards of care at centers with quality/volume standards. $^{15,20,21}$

11. In the clinical scenarios, no unusual extenuating circumstances exist (eg, an inability to comply with antiplatelet agents, do-not-resuscitate status, a patient unwilling to consider revascularization, technical reasons rendering revascularization infeasible, or comorbidities likely to markedly increase procedural risk). If any of these circumstances exist, it is critical that the clinician provide adequate documentation in the medical record to support exclusions from the AUC and the alternative management decisions made in the patient.

12. Patient history and physical examination are assumed to be comprehensive and thorough. Descriptions of the patient's symptoms are assumed to accurately represent the current status of the patient (eg, asymptomatic patients are truly asymptomatic rather than asymptomatic due to self-imposed lifestyle limitations).
13. When PCI is being considered in patients with multivessel disease, it may be clinically prudent to perform the procedures in a sequential fashion (so-called "staged procedures"). If this is the initial management plan, the intent for a staged procedure should be clearly outlined and the appropriateness rating should apply to the entire revascularization procedure. Specifically, planned staged procedures should not be assessed by individual arteries but rather in terms of the plan for the entire revascularization strategy. For data collection purposes, this will require documenting how the procedure is staged (either PCI or hybrid revascularization with surgery), and it is assumed that all stenoses covered under the umbrella of the planned staged procedure are functionally significant.

14. Although the clinical scenarios should be rated on the basis of the published literature, the writing committee acknowledges that decisions about coronary artery revascularization in patient populations that are poorly represented in the literature are still required in daily practice. Therefore, rating panel members should assume that some of the clinical scenarios presented will have low levels of evidence to guide rating decisions. Key to the application of the AUC in settings where there are extenuating circumstances or low levels of supporting evidence is enhanced documentation by the clinician to support the clinical decisions made.

15. As with all previously published clinical policies, deviations by the rating panel from prior published documents were directed by new evidence that justifies such evolution. However, the reader is advised to pay 
careful attention to the wording of an indication in the present document when making comparisons to prior publications.

16. Indication ratings contained herein supersede the ratings of similar indications contained in previous AUC coronary revascularization documents.

\section{Assumptions for Rating Multiple Treatment Options}

1. The goal of this document is to identify revascularization treatments that are considered reasonable for a given clinical indication. Therefore, each treatment option (PCI or CABG) should be rated independently for its level of appropriateness in the specific clinical scenario, rather than being placed into a forced or artificial rankorder comparison against each other. Identifying options that may or may not be reasonable for specific indications is the goal of this document, rather than determining a single best treatment for each clinical indication or a rank-order. Therefore, more than 1 treatment or even all treatments may be considered "Appropriate," "May Be Appropriate," or "Rarely Appropriate" for any given clinical indication.

2. If more than 1 treatment falls into the same appropriate use category, it is assumed that patient preference combined with physician judgment and available local expertise will be used to determine the final treatment used.

\section{DEFINITIONS}

Definitions of some key terms used throughout the scenarios are shown in the following text. A complete set of definitions is found in Appendix A. These definitions were provided to and discussed with the rating panel before the rating process started.

\section{Indication}

A set of patient-specific conditions defines an "indication." The term "clinical indication" (used interchangeably with "clinical scenario") provides the context for the rating of therapeutic options. However, an "appropriate" rating assigned by the rating panel does not necessarily mean the therapy is mandatory, nor does a "rarely appropriate" rating mean it is prohibited.

\section{Risk Factor Modification (Secondary Prevention) and Antianginal Medical Therapy}

As previously stated, the indications assume that patients are receiving all indicated treatments for the secondary prevention of cardiovascular events. This includes lifestyle and pharmacological interventions according to guidelinebased recommendations. Antianginal medical therapy is incorporated into the structure of the rating tables and should follow the recommendations of the SIHD guideline, with a beta blocker as initial therapy and the option to administer calcium channel blockers, long-acting nitrates, and/or ranolazine if the beta blocker is ineffective or not tolerated. $^{3,4}$

Specific target doses of drugs are not provided as this must be individualized, but for beta blockers, it is assumed the dose is sufficient to blunt the exercise heart rate without causing intolerable fatigue, bradycardia, or hypotension. It is assumed that the maximally tolerated dose of beta blockers is being used before the addition of other drugs, and when other drugs are added, the dose is titrated to alleviate symptoms or is also the maximally tolerated dose. Using multiple drugs at less than optimal doses is an inefficient and expensive strategy. The SIHD guideline recommends calcium channel blockers or long-acting nitrates if beta blockers are contraindicated or cause unacceptable side effects. The SIHD guideline also recommends adding calcium channel blockers or long-acting nitrates to beta blockers for relief of symptoms when initial treatment with beta blockers is unsuccessful. Initiating, continuing, or intensifying antianginal therapy is integrated into the ratings tables along with revascularization options, as this is typical of real-world practice.

\section{Stress Testing and Risk of Findings on Noninvasive Testing}

Stress testing is commonly used for both diagnosis and risk stratification of patients with CAD. Therapies to improve survival in patients with SIHD are outlined in detail in the 2012 SIHD guideline (Table A). ${ }^{3}$ The various noninvasive findings associated with high $(>3 \%$ annual death or myocardial infarction), intermediate ( $1 \%$ to $3 \%$ annual death or myocardial infarction) and low $(<1 \%$ annual death or myocardial infarction) risk are outlined in Table B. It is important to note that this table includes several noninvasive findings apart from a stress test, such as resting $\mathrm{LV}$ function and a high coronary calcium score in the assessment of risk. These were not specifically included in the indications of this AUC, but should be considered as part of the patient profile described in an indication, especially when high and intermediate risk are used in the indication.

\section{Vessel Disease}

The construct used to characterize the extent of CAD is based on the common clinical use of the terms 1-, 2-, and 3 -vessel disease and left main disease, although it is recognized that individual coronary anatomy is highly variable. In general, these terms refer to a significant stenosis in 1 of the 3 major coronary arteries (right coronary artery, LAD, or circumflex) or their major branches. With the exception of the proximal LAD, which specifically refers to the segment of the LAD proximal to the first major septal and diagonal, the terms 1-, 2-, and 3-vessel disease do not 
define the location (ie, proximal, mid, or distal) of the stenosis in the artery, which is frequently related to the amount of myocardium at risk. Furthermore, the classification of diseased vessels does not consider coronary dominance, although in practical terms, most consider individuals with significant disease in the LAD and a left dominant circumflex to have 3-vessel involvement. Coronary anomalies are also not considered in this construct. Although imperfect, the commonly used classification of 1-, 2-, and 3 -vessel disease and left main disease remains widely used in clinical practice. Within the context of this document, the terms 1-, 2-, and 3-vessel disease should be assumed to mean that each vessel involved (whether the main vessel or a major side branch) provides flow to a sufficient amount of myocardium to be clinically important. The anatomic definition of 1-, 2-, or 3-vessel disease is now often augmented by the physiological testing of stenosis significance (eg, FFR), which can reclassify the hemodynamic significance of a stenosis. In the setting of PCI, when FFR in an artery is $>0.80$, treatment is deferred and the clinical scenario considered should be reclassified to be consistent with the number of significant stenoses. In other words, if the angiogram suggests 2 significant stenoses, but FFR testing indicates that only 1 is significant, the clinical scenario considered should be from the group with 1-vessel CAD. Although there are considerable data to support FFR-directed PCI treatment as an option, this concept is not well-established for surgical revascularization. ${ }^{22,23}$

\section{Ischemic Symptoms}

Angina pectoris is usually described as a discomfort (not necessarily pain) in the chest or adjacent areas. It is variably described as tightness, heaviness, pressure, squeezing, or a smothering sensation. In some patients, the symptom may be a more vague discomfort, a numbness, or a burning sensation. Alternatively, so-called anginal equivalents such as dyspnea, faintness, or fatigue may occur. The location is usually substernal and radiation may occur to the neck, jaw, arms, back, or epigastrium. Isolated epigastric discomfort or pain in the lower mandible may rarely be a symptom of myocardial ischemia. The typical episode of angina pectoris begins gradually and reaches its maximum intensity over a period of minutes. Typical angina pectoris is precipitated by exertion or emotional stress and is relieved within minutes by rest or nitroglycerin. Because of the variation in symptoms that may represent myocardial ischemia, the clinical scenarios are presented using the broad term "ischemic symptoms" to capture this concept.

This AUC document is specific for patients with SIHD. Therefore, by definition, there are no Canadian Cardiovascular Society Class 4 patients. Because of the variety of symptoms that may indicate myocardial ischemia, individual patient variation in how they are described and observer variability in the assessment of symptom severity, the writing group chose not to use the Canadian Cardiovascular Society classification system in this document. ${ }^{24,25}$ Symptom status of the patient was broadly classified into asymptomatic or simply ischemic symptoms, emphasizing the use of more objective measures of ischemia within each indication to stratify patients into low-risk or intermediate-/high-risk findings.

\section{Invasive Methods of Determining Hemodynamic Significance}

The writing group recognizes that not all patients referred for revascularization will have previous noninvasive testing. In fact, there are several situations in which patients may be appropriately referred for coronary angiography on the basis of symptom and ECG presentation and a high pretest probability of CAD. In these settings, there may be situations where angiography shows a coronary narrowing of questionable hemodynamic importance in a patient with symptoms that can be related to myocardial ischemia. In such patients, the use of additional invasive measurements (such as FFR or intravascular ultrasound) at the time of diagnostic angiography may be very helpful in further defining the need for revascularization and may substitute for stress test findings. Accordingly, many of the indications now include FFR test results.

\section{The Role of Patient Preference in the AUC}

Patients often make decisions about medical treatments without a complete understanding of their options. Patient participation or shared decision making (SDM) describes a collaborative approach whereby patients are provided with evidence-based information on treatment choices and encouraged to use the information in an informed dialogue with their provider to make decisions that not only use the scientific evidence, but also align with their values, preferences, and lifestyle. ${ }^{26-28}$ The alternative decision paradigm, often referred to as medical paternalism, places decision authority with physicians and assigns the patient a more passive role. ${ }^{29}$ SDM respects both the provider's knowledge and the patient's right to be fully informed of all care options with their associated risks and benefits. SDM often uses decision aids such as written materials, online modules, or videos to present information about treatment options that help the patient evaluate the risks and benefits of a particular treatment. The most effective decision aids to help patients make truly informed decisions provide relevant facts and videos of real patient perspectives regarding the particular treatment. ${ }^{30}$ Many professional organizations now endorse SDM in practice. ${ }^{31,32}$

More than 1 treatment option often exists with no clear evidence identifying the best option. This is compounded when there is variation in experts' recommendations about the best treatment under different circumstances. ${ }^{33} \mathrm{~A}$ challenging situation exists when scientific data suggest 1 treatment is likely to have better outcomes, yet the patient 
TABLE A. Revascularization to improve survival compared with medical therapy

\begin{tabular}{|c|c|c|c|}
\hline $\begin{array}{l}\text { Anatomic } \\
\text { Setting }\end{array}$ & COR & LOE & References \\
\hline \multicolumn{4}{|c|}{ UPLIM or complex CAD } \\
\hline CABG and PCI & 1-Heart Team approach recommended & $\mathrm{C}$ & $(950-952)$ \\
\hline CABG and $\mathrm{PCI}$ & Ila-Calculation of STS and SYNTAX scores & B & $(949,950,953-957)$ \\
\hline \multicolumn{4}{|l|}{ UPLM* $^{*}$} \\
\hline CABG & 1 & B & $(73,381,412,959-962)$ \\
\hline \multirow[t]{5}{*}{$\mathbf{P C l}$} & $\begin{array}{l}\text { Ila-For SIHD when both of the following are present: } \\
\text { Anatomic conditions associated with a low risk of PCI procedural complications and a high likelihood of } \\
\text { good long-term outcome (eg, a low SYNTAX score of } \leq 22 \text {, ostial or trunk left main CAD) } \\
\text { - Clinical characteristics that predict a significantly increased risk of adverse surgical outcomes } \\
\text { (eg, STS-predicted risk of operative mortality } \geq 5 \%)\end{array}$ & B & $(949,953,955,958,963-980)$ \\
\hline & Ila-For UA/NSTEMI if not a CABG candidate & B & $(949,968-971,976-979,981)$ \\
\hline & $\begin{array}{l}\text { Ila-For STEMI when distal coronary flow is TIMI flow grade }<3 \text { and } \mathrm{PCI} \text { can be performed more } \\
\text { rapidly and safely than CABG }\end{array}$ & C & $(965,982,983)$ \\
\hline & $\begin{array}{l}\text { IIb-For SIHD when both of the following are present: } \\
\text { Anatomic conditions associated with a low to intermediate risk of PCI procedural complications } \\
\text { and an intermediate to high likelihood of good long-term outcome (eg,low-intermediate } \\
\text { SYNTAX score of }<33 \text {, bifurcation left main CAD) } \\
\text { Clinical characteristics that predict an increased risk of adverse surgical outcomes } \\
\text { (eg, moderate-severe COPD, disability from prior stroke, or prior cardiac surgery; } \\
\text { STS-predicted operative mortality }>2 \% \text { ) }\end{array}$ & B & $(949,953,955,958,963-980,984)$ \\
\hline & $\begin{array}{l}\text { III: Harm-For SIHD in patients (versus performing } C A B G \text { ) with unfavorable anatomy for } \mathrm{PCI} \text { and who are } \\
\text { good candidates for CABG }\end{array}$ & B & $(73,381,412,949,953,955,959-964)$ \\
\hline \multicolumn{4}{|c|}{ 3-vessel disease with or without proximal LAD artery disease* } \\
\hline \multirow[t]{2}{*}{ CABG } & I & B & $(353,412,959,985-987)$ \\
\hline & $\begin{array}{l}\text { Ila-It is reasonable to choose CABG over PCI in patients with complex 3-vessel CAD } \\
(\text { eg, SYNTAX score }>22) \text { who are good candidates for CABG. }\end{array}$ & B & $(964,980,987-989)$ \\
\hline $\mathbf{P C l}$ & Ilb-Of uncertain benefit & B & $(366,959,980,985,987)$ \\
\hline \multicolumn{4}{|c|}{ 2-vessel disease with proximal LAD artery disease* } \\
\hline CABG & 1 & B & $(353,412,959,985-987)$ \\
\hline PCI & Ilb-Of uncertain benefit & B & $(366,959,985,987)$ \\
\hline
\end{tabular}

2-vessel disease without proximal LAD artery disease*

\begin{tabular}{l|l|l|}
\hline CABG & Ila-With extensive ischemia & B \\
& Ilb-Of uncertain benefit without extensive ischemia & C \\
\hline PCI & Ilb-Of uncertain benefit & B \\
\hline
\end{tabular}

$(327,990-992)$

(987)

$(366,959,985,987)$

1-vessel proximal LAD artery disease

1-vesset proximal LAD artery disease

\begin{tabular}{l|ll} 
CABG & Ila-With LIMA for long-term benefit & B \\
\hline PCI & Ilb-Of uncertain benefit & B
\end{tabular}

1-vessel disease without proximal LAD artery involvement

\begin{tabular}{l|lll}
\hline CABG & III: Harm & B \\
\hline PCI & III: Harm & B \\
\hline
\end{tabular}

LV dysfunction

\begin{tabular}{l|ll}
\hline CABG & Ila-EF $35 \%$ to $50 \%$ & B \\
\hline CABG & Ilb-EF $<35 \%$ without significant left main CAD & B \\
\hline PCI & Insufficient data &
\end{tabular}

Survivors of sudden cardiac death with presumed ischemia-mediated VT

\begin{tabular}{|c|c|c|c|}
\hline CABG & 1 & B & $(350,1003,1004)$ \\
\hline $\mathrm{PCl}$ & I & C & (1003) \\
\hline
\end{tabular}

No anatomic or physiological criteria for revascularization

\begin{tabular}{l|ll|c|c|}
\hline CABG & III: Harm & $(306,327,412,985,990,995-998)$ & B \\
\hline PCI & III: Harm & $(306,327,412,985,990,995-998)$ \\
\hline
\end{tabular}

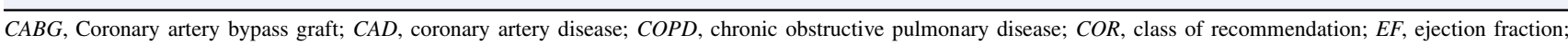
$L A D$, left anterior descending; $L I M A$, left internal mammary artery; $L O E$, level of evidence; $L V$, left ventricular; N/A, not available; $P C I$, percutaneous coronary intervention; SIHD, stable ischemic heart disease; STEMI, ST-elevation myocardial infarction; STS, Society of Thoracic Surgeons; SYNTAX, Synergy between Percutaneous Coronary Intervention with TAXUS and Cardiac Surgery; TIMI, Thrombolysis In Myocardial Infarction; UA/NSTEMI, unstable angina/non-ST-elevation myocardial infarction; UPLM, unprotected left main disease; $V T$, ventricular tachycardia. *In patients with multivessel disease who also have diabetes mellitus, it is reasonable to choose CABG (with LIMA) over PCI (30,991,1005-1011) (Class IIa; LOE: B). Reproduced from Fihn et al. 
TABLE B. Noninvasive risk stratification

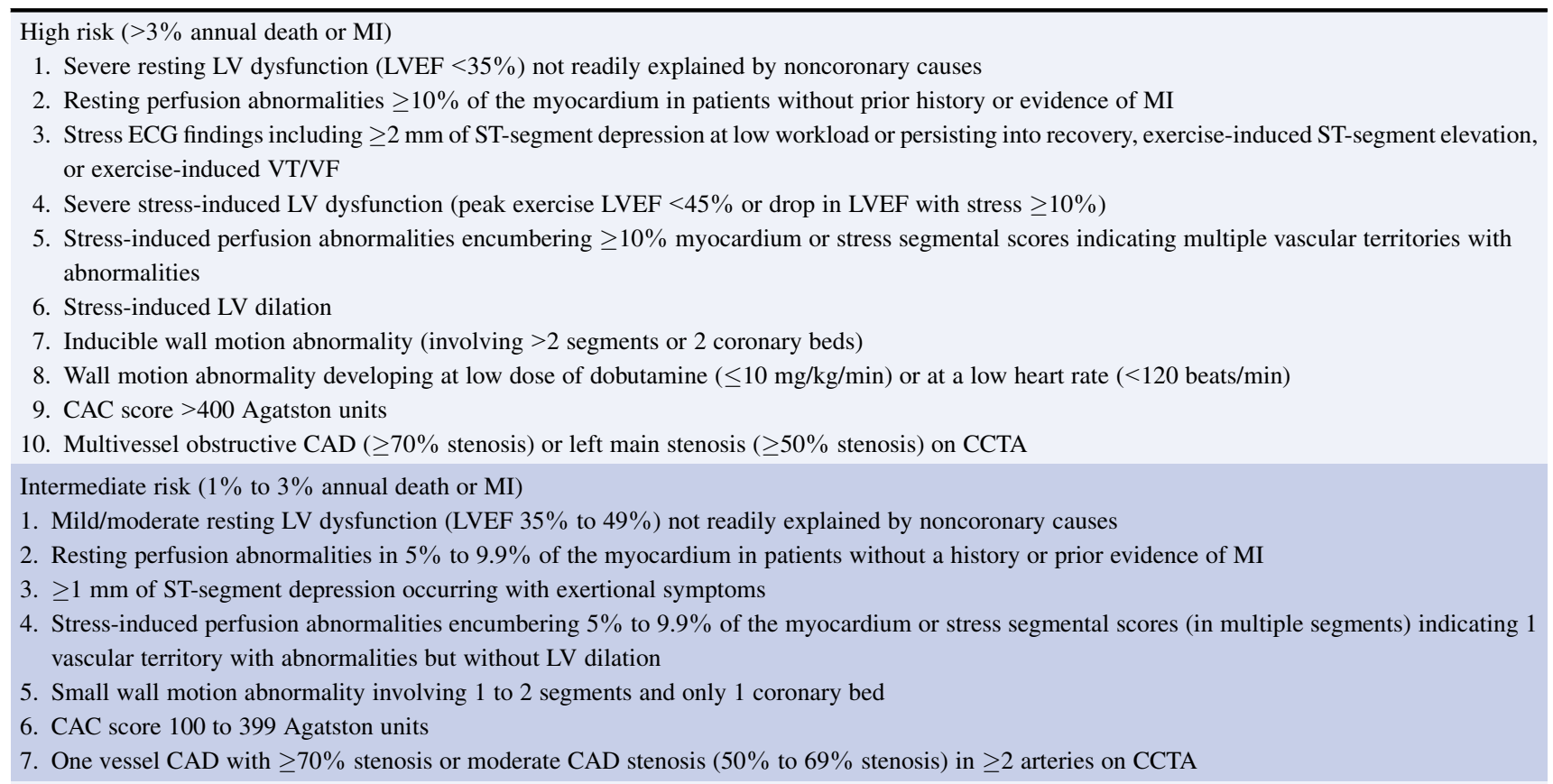

Low risk $(<1 \%$ annual death or MI)

1. Low-risk treadmill score (score $\geq 5$ ) or no new ST segment changes or exercise-induced chest pain symptoms; when achieving maximal levels of exercise

2. Normal or small myocardial perfusion defect at rest or with stress encumbering $<5 \%$ of the myocardium*

3. Normal stress or no change of limited resting wall motion abnormalities during stress

4. CAC score $<100$ Agaston units

5. No coronary stenosis $>50 \%$ on CCTA

$C A C$, Coronary artery calcium; $C A D$, coronary artery disease; $C C T A$, coronary computed tomography angiography; $L V$, left ventricular; $L V E F$, left ventricular ejection fraction; $M I$, myocardial infarction. *Although the published data are limited; patients with these findings will probably not be at low risk in the presence of either a high-risk treadmill score or severe resting LV dysfunction (LVEF $<35 \%$ ). Reproduced from Fihn et al.

prefers an alternative treatment. Within the context of the AUC, this would be manifest as the patient requesting a therapy with a lower AUC rating (eg, wanting a therapy rated as rarely appropriate when a therapy rated appropriate exists). Informed consent is fundamental to SDM. ${ }^{34}$ Without understanding the pros and cons of all treatment options, patients cannot properly engage in SDM and blend their personal desires with the scientific data. Without question, it is important that blending AUC ratings into clinical decision making provide a pathway for including patient preference and SDM. However, the mechanism for that process is beyond the scope of this AUC document. The purpose of this document is to develop clinical scenarios and provide ratings of those scenarios by an expert panel. A complete discussion about treatment options with SDM can only be finalized once the category of appropriate use is determined.

\section{ABBREVIATIONS}

$$
\begin{aligned}
& \text { AA = antianginal } \\
& \text { ACS = acute coronary syndrome } \\
& \text { AUC = appropriate use criteria }
\end{aligned}
$$

\author{
$\mathrm{BB}=$ beta-blockers \\ $\mathrm{CABG}=$ coronary artery bypass graft \\ $\mathrm{CAD}=$ coronary artery disease \\ $\mathrm{FFR}=$ fractional flow reserve \\ IMA = internal mammary artery \\ $\mathrm{LAD}=$ left anterior descending coronary artery \\ LVEF $=$ left ventricular ejection fraction \\ $\mathrm{PCI}=$ percutaneous coronary intervention \\ SIHD $=$ stable ischemic heart disease
}

\section{CORONARY REVASCULARIZATION IN PATIENTS WITH STABLE ISCHEMIC HEART DISEASE: APPROPRIATE USE CRITERIA (BY INDICATION)}

\section{Section 1. SIHD Without Prior CABG}

The format for tables in Section 1 is similar, with separate tables for 1-, 2-, and 3-vessel disease and left main disease. The columns in each table are stratified into 2 categories. There is a single column combining patients who are 
asymptomatic and not receiving antianginal therapy with patients who are asymptomatic and receiving antianginal therapy. The remaining columns are devoted to patients with ischemic symptoms, with 3 separate categories: ischemic symptoms and receiving no antianginal therapy, ischemic symptoms and receiving 1 antianginal drug (beta blocker preferred), and ischemic symptoms receiving 2 or more antianginal drugs. As outlined in the SIHD guideline, in the absence of contraindications, initial therapy should be a beta blocker prescribed at a dose that reduces heart rate without excessive resting bradycardia, hypotension, or fatigue. Other antianginal drugs are then added to beta blockers depending on the individual needs of the patient until symptoms are suppressed to the satisfaction of the patient or higher doses cannot be used because of side effects. In each of the subordinate columns, the panel was asked to rate the options for revascularization, specifically PCI or CABG. As noted earlier, the rating panel was asked to rate each revascularization option independent of the other, with the intent to rate each therapy on its own merits rather than in comparison to the other option. In this construct, both revascularization options could be assigned identical ratings.

In this and subsequent tables, clinical scenarios often contain the phrase "noninvasive testing." In this document, that phrase includes all forms of stress testing using either dynamic or pharmacological stress that may be coupled with various imaging tests. It also could include other imaging, such as coronary computed tomography angiography or magnetic resonance imaging, to assess myocardial viability. Some would favor the term "functional testing," but the writing committee did not view this as inclusive of computed tomography or magnetic resonance imaging and thus favored the term "noninvasive testing." FFR is considered as part of an invasive evaluation and is cited separately in some scenarios. An emerging technology, computed tomography-derived FFR is a combination technique that is noninvasive like computed tomography but provides FFR, which has traditionally only been an invasive test.

Table 1.1. One-vessel disease. Similar to the 2011 CABG and 2012 SIHD guidelines, this document uses proximal LAD disease as an additional anatomic discriminator for 1-vessel CAD. Although data are minimal, the writing committee felt that proximal disease of a dominant circumflex should be considered as high-risk anatomy with similar implications as proximal LAD disease, and thus, it was considered in a separate section along with proximal LAD disease. Table 1.2. Two-vessel disease. The format of this table is similar to that for 1-vessel disease. Similar to the 2011 CABG and 2012 SIHD guidelines, this document makes a distinction regarding the presence or absence of proximal LAD disease. The writing group did not add proximal left dominant circumflex disease as an additional discriminator, because most would consider an isolated stenosis in this location to be the equivalent of 2-vessel disease (ie, right coronary artery and circumflex disease). Following this construct, the combination of proximal LAD disease and proximal left dominant circumflex disease would be considered as 3-vessel disease and rated using the 3-vessel disease table (Table 1.3.). In the absence of exercise data, invasive physiological testing of both involved vessels is included in several of the indications. To remain in this table of 2-vessel disease, such testing must be abnormal in both vessels. If this testing shows only 1 vessel to be abnormal, the patient would no longer be rated using this table, but rather would be rated in the table for 1-vessel CAD. Finally, because of the increasing body of literature that has identified diabetes as an important factor to consider when recommending revascularization, scenarios indicating the presence of diabetes are provided.

Table 1.3. Three-vessel disease. Similar to Table 1.2., because of the increasing body of literature that has identified diabetes as an important factor to consider when recommending revascularization, categories indicating the presence or absence of diabetes are provided among the individual indications. Stenosis complexity is also an important factor to consider in any revascularization procedure, probably more so for PCI than for CABG. The SYNTAX (Synergy between Percutaneous Coronary Intervention with TAXUS and Cardiac Surgery) trial provided a comprehensive comparison of PCI and CABG and a structure that may be helpful in formulating revascularization recommendations. ${ }^{35}$ Factors such as vessel occlusion, bifurcation or trifurcation at branch points, ostial stenosis location, length $>20 \mathrm{~mm}$, tortuosity, calcification, and thrombus all add to the complexity of PCI. The presence of multiple complex features (SYNTAX score $>22$ ) is associated with more favorable outcomes with CABG. Although limitations of the SYNTAX score for certain revascularization recommendations are recognized and it may be impractical to apply this scoring system to all patients with multivessel disease, it is a reasonable surrogate for the extent and complexity of CAD and provides important information that can be helpful when making revascularization decisions.

Accordingly, in this table specifically for patients with 3 -vessel disease, the rating panel was asked to consider the indications in patients with low complexity compared with those with intermediate and high complexity.

Table 1.4. Left main coronary artery stenosis. Literature on the treatment of significant left main disease is dominated by surgical revascularization procedures and, more recently, comparisons with PCI in some anatomic situations. There are data suggesting that stenting of the left main ostium or trunk is more straightforward than treating distal bifurcation or trifurcation stenoses and is associated with a lower rate of restenosis. In comparison, 
TABLE 1.1. One-vessel disease

\begin{tabular}{|c|c|c|c|c|c|c|c|c|c|}
\hline \multicolumn{10}{|c|}{ Appropriate Use Score (1-9) } \\
\hline \multicolumn{10}{|c|}{ One-Vessel Disease } \\
\hline & & \multicolumn{2}{|c|}{ Asymptomatic } & \multicolumn{6}{|c|}{ Ischemic Symptoms } \\
\hline & & \multicolumn{2}{|c|}{$\begin{array}{l}\text { Not on AA } \\
\text { Therapy or With } \\
\text { AA Therapy }\end{array}$} & \multicolumn{2}{|c|}{$\begin{array}{l}\text { Not on AA } \\
\text { Therapy }\end{array}$} & \multicolumn{2}{|c|}{$\begin{array}{l}\text { On } 1 \text { AA Drug } \\
\text { (BB Preferred) }\end{array}$} & \multicolumn{2}{|c|}{ On $\geq 2$ AA Drugs } \\
\hline \multicolumn{2}{|c|}{ Indication } & PCI & CABG & $\mathbf{P C l}$ & CABG & $\mathbf{P C I}$ & CABG & $\mathbf{P C l}$ & CABG \\
\hline \multicolumn{10}{|c|}{ No Proximal LAD or Proximal Left Dominant LCX Involvement } \\
\hline 1. & - Low-risk findings on noninvasive testing & $\mathbf{R}(2)$ & $\mathbf{R}(1)$ & $\mathbf{R}(3)$ & $\mathbf{R}(2)$ & M (4) & $\mathbf{R}(3)$ & A (7) & M (5) \\
\hline 2. & $\begin{array}{l}\text { - Intermediate- or high-risk findings on } \\
\text { noninvasive testing }\end{array}$ & M (4) & $\mathbf{R}(3)$ & M (5) & M (4) & M (6) & M (4) & $A(8)$ & M (6) \\
\hline 3. & $\begin{array}{l}\text { No stress test performed or, if performed, } \\
\text { results are indeterminate } \\
\text { - FFR } \leq 0.80^{*}\end{array}$ & M (4) & $R(2)$ & M (5) & $\mathbf{R}(3)$ & $M(6)$ & M (4) & $A(8)$ & M (6) \\
\hline \multicolumn{10}{|c|}{ Proximal LAD or Proximal Left Dominant LCX Involvement Present } \\
\hline 4. & - Low-risk findings on noninvasive testing & M (4) & $\mathbf{R}(3)$ & M (4) & M (4) & M (5) & M (5) & A (7) & $A(7)$ \\
\hline 5. & $\begin{array}{l}\text { - Intermediate- or high-risk findings on } \\
\text { noninvasive testing }\end{array}$ & M (5) & M (5) & M (6) & M (6) & $A(7)$ & $A(7)$ & $A(8)$ & $A(8)$ \\
\hline 6. & $\begin{array}{l}\text { - No stress test performed or, if performed, } \\
\text { results are indeterminate } \\
\text { - FFR } \leq 0.80\end{array}$ & M (5) & M (5) & M (6) & M (6) & M (6) & $M(6)$ & $A(8)$ & $A(7)$ \\
\hline
\end{tabular}

The number in parentheses next to the rating reflects the median score for that indication. *Substitution of a newer coronary pressure ratio that does not require hyperemia for FFR may be considered provided the appropriate reference values are used. $A$, Appropriate; $A A$, antianginal; $B B$, beta blockers; $C A B G$, coronary artery bypass graft; $F F R$, fractional flow reserve; $L A D$, left anterior descending coronary artery; $L C X$, left circumflex artery; $M$, may be appropriate; $P C I$, percutaneous coronary intervention; $R$, rarely appropriate.

left main lesion location has a negligible influence on the success and long-term results of CABG. Accordingly, there are separate rating options for ostial and mid-shaft left main disease and distal or bifurcation left main disease. The definition of a significant left main stenosis used herein is $\geq 50 \%$ narrowing by angiography. However, the angiographic assessment of the severity of left main disease has several shortcomings, and other assessments such as IVUS or FFR may be needed. For left main coronary artery stenoses, a minimum lumen diameter of $<2.8 \mathrm{~mm}$ or a minimum lumen area of $<6 \mathrm{~mm}^{2}$ suggests a physiologically significant lesion. It has been suggested that a minimum lumen area $>7.5 \mathrm{~mm}^{2}$ suggests revascularization may be safely deferred. A minimum lumen area between 6 and $7.5 \mathrm{~mm}^{2}$ requires further physiological assessment, such as measurement of FFR. Alternatively, FFR may be used as the first modality to assess ambiguous left main severity, and the criteria for a significant stenosis are the same as for non-left main stenosis. . $^{21,36,37}$

\section{Section 2. Tables 2.1 and 2.2 SIHD With Prior CABG}

Patients with prior CABG surgery can present with a wide spectrum of disease progression. This includes the development of new obstructive disease in coronary arteries not bypassed in the first operation, new stenoses in existing bypass grafts, and territory previously bypassed but jeopardized again because of graft occlusion. Developing indications inclusive of all of these anatomic possibilities would be impractical. Accordingly, the writing committee adopted a more compact construct based on the presence of a significant stenosis in a bypass graft or native coronary artery supplying 1,2 , or 3 distinct vascular territories roughly corresponding to the territories of the 3 main coronary arteries. As in patients without prior $\mathrm{CABG}$, the indications included an assessment of risk based on noninvasive testing (low versus intermediate or high risk).

Evaluation of the severity and physiological significance of a stenosis in saphenous vein grafts (SVG) can be particularly challenging because of the usual marked size difference between the SVG and native artery. Although FFR measurements are well-validated in native vessels, data on the use of FFR in vein grafts are limited. ${ }^{38}$ After CABG surgery, the bypass conduit should act in a similar fashion to the native, low-resistance epicardial vessel. However, the assessment of ischemia due to a stenosis in a vein graft is complicated by several features, which include: 1) the potential for competing flow (and pressure) from both the native and conduit vessels; 2) the presence of collaterals from longstanding native coronary occlusion; and 3) the potential for microvascular abnormalities due to ischemic fibrosis and scarring, pre-existing or bypass surgeryrelated myocardial infarction, or chronic low-flow ischemia. Despite these complicating features, the theory of FFR should apply equally to both a lesion in an SVG to the right coronary artery feeding a normal myocardial bed and a lesion in the native right coronary. However, if the native and collateral supply are sufficiently large, the FFR across an SVG stenosis could be normal. FFR measurements may be most useful in the setting of an occluded bypass graft to a native artery with an intermediate-severity stenosis. FFR measurements in 
TABLE 1.2. Two-vessel disease

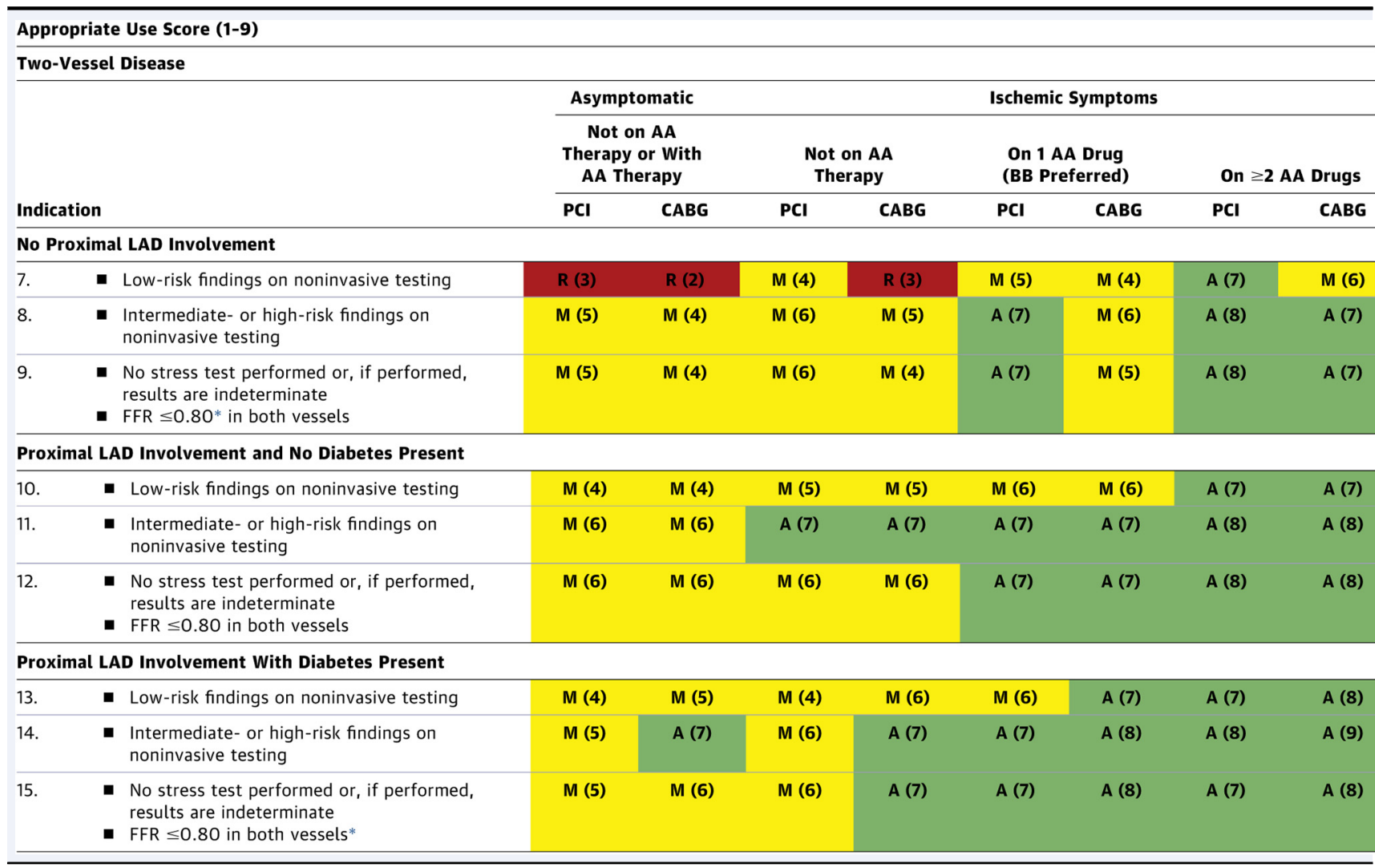

The number in parentheses next to the rating reflects the median score for that indication. $A$, Appropriate; $A A$, antianginal; $B B$, beta blockers; $C A B G$, coronary artery bypass graft; $F F R$, fractional flow reserve; $L A D$, left anterior descending coronary artery; $M$, may be appropriate; $P C I$, percutaneous coronary intervention; $R$, rarely appropriate. * Substitution of a newer coronary pressure ratio that does not require hyperemia for FFR may be considered provided the appropriate reference values are used.

bypass grafts are less well-validated and should thus be interpreted with caution.

Two tables are presented for the rating of patients with prior $\mathrm{CABG}$ depending on the patency of an existing internal mammary artery (IMA) graft. IMAs have a greater long-term patency rate than SVGs-typically $>90 \%$ after 10 years. ${ }^{39,40}$ Accordingly, use of the IMA as a conduit in CABG surgery has steadily increased. Current use is $98 \%$, as reported in the Society of Thoracic Surgeons national database, and use of the IMA as a conduit is 1 of the quality metrics in their composite score. Because of the current high use of the IMA, the writing committee felt there were too few patients to consider a separate category consisting of patients who only had SVGs used in their first operation, although a few such patients may exist. Moreover, the writing committee did not develop any scenarios where the initial operation consisted of only bypass grafts to the circumflex and right coronary artery in the absence of LAD disease. The patency and longevity of the IMA as a bypass graft was felt by the writing committee to be an important decision point in the indication development, as many cardiovascular surgeons are hesitant to perform a second bypass operation in the presence of a patent and fully functional IMA graft, especially to the LAD. The path of the IMA, particularly if it courses medially or is adherent to the back of the sternum, may be at greater risk during sternal re-entry, with adverse consequences even if the IMA-grafted vessel is regrafted. For Table 2.1., it is assumed that the LAD was significantly diseased at the time of the original operation. Therefore, if the IMA to the LAD is no longer patent or is severely diseased, it is assumed that the native LAD is also severely diseased or occluded.

\section{Section 3. Table 3.1 SIHD Undergoing Procedures for Which Coronary Revascularization May Be Considered}

In an effort to capture common clinical scenarios that are not well-represented in guidelines, the writing group developed indications for preoperative revascularization in patients being evaluated for renal transplantation or structural heart procedures. The writing committee recognized that pre-operative revascularization is sometimes requested before transplantation of other organs, but there is insufficient experience or data from controlled studies 
TABLE 1.3. Three-vessel disease

\begin{tabular}{|c|c|c|c|c|c|c|c|c|c|}
\hline \multicolumn{10}{|c|}{ Appropriate Use Score (1-9) } \\
\hline \multicolumn{10}{|c|}{ Three-Vessel Disease } \\
\hline & & \multicolumn{2}{|c|}{ Asymptomatic } & & & \multicolumn{4}{|c|}{ Ischemic Symptoms } \\
\hline & & \multicolumn{2}{|c|}{$\begin{array}{l}\text { Not on AA } \\
\text { Therapy or With } \\
\text { AA Therapy }\end{array}$} & \multicolumn{2}{|c|}{$\begin{array}{l}\text { Not on AA } \\
\text { Therapy }\end{array}$} & \multicolumn{2}{|c|}{$\begin{array}{l}\text { On } 1 \text { AA Drug } \\
\text { (BB Preferred) }\end{array}$} & \multicolumn{2}{|c|}{ On $\geq 2$ AA Drugs } \\
\hline \multicolumn{2}{|c|}{ Indication } & PCI & CABG & PCI & CABG & PCI & CABG & PCI & CABG \\
\hline \multicolumn{10}{|c|}{ Low Disease Complexity (eg, Focal Stenoses, SYNTAX $\leq \mathbf{2 2}$ ) } \\
\hline 16. & $\begin{array}{l}\text { - Low-risk findings on noninvasive testing } \\
\text { - No diabetes }\end{array}$ & M (4) & M (5) & M (5) & M (5) & M (6) & M (6) & $A(7)$ & $A(7)$ \\
\hline 17. & $\begin{array}{l}\text { - Intermediate- or high-risk findings on } \\
\text { noninvasive testing } \\
\text { - No diabetes }\end{array}$ & M (6) & A (7) & $A(7)$ & $A(7)$ & $A(7)$ & A (8) & A (8) & A (8) \\
\hline 18. & $\begin{array}{l}\text { - Low-risk findings on noninvasive testing } \\
\text { - Diabetes present }\end{array}$ & M (4) & M (6) & M (5) & M (6) & M (6) & $A(7)$ & $A(7)$ & A (8) \\
\hline 19. & $\begin{array}{l}\text { - Intermediate- or high-risk findings on } \\
\text { noninvasive testing } \\
\text { - Diabetes present }\end{array}$ & M (6) & $A(7)$ & M (6) & A (8) & $A(7)$ & A (8) & $A(7)$ & $A(9)$ \\
\hline \multicolumn{10}{|c|}{ Intermediate or High Disease Complexity (eg, Multiple Features of Complexity as Noted Previously, SYNTAX >22) } \\
\hline 20. & $\begin{array}{l}\text { - Low-risk findings on noninvasive testing } \\
\text { - No diabetes }\end{array}$ & M (4) & M (6) & M (4) & A (7) & M (5) & A (7) & M (6) & A (8) \\
\hline 21. & $\begin{array}{l}\text { - Intermediate- or high-risk findings on } \\
\text { noninvasive testing } \\
\text { - No diabetes }\end{array}$ & M (5) & A (7) & M (6) & A (7) & M (6) & A (8) & M (6) & A (9) \\
\hline 22. & $\begin{array}{l}\text { - Low-risk findings on noninvasive testing } \\
\text { - Diabetes present }\end{array}$ & M (4) & A (7) & M (4) & $A(7)$ & M (5) & $A(8)$ & M (6) & $A(9)$ \\
\hline 23. & $\begin{array}{l}\text { - Intermediate- or high-risk findings on } \\
\text { noninvasive testing } \\
\text { - Diabetes present }\end{array}$ & M (4) & $A(8)$ & M (5) & $A(8)$ & M (5) & $A(8)$ & M (6) & $A(9)$ \\
\hline
\end{tabular}

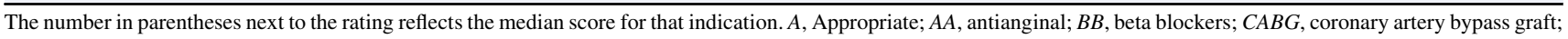
$M$, may be appropriate; $P C I$, percutaneous coronary intervention; SYNTAX, Synergy between PCI with Taxus and Cardiac Surgery trial.

upon which to develop meaningful scenarios. These scenarios do not capture all possible clinical situations, but were felt to capture the majority of common clinical situations. If patients have an acute coronary syndrome, the writing group felt they should be rated according to the AUC for acute coronary syndrome. For many of these patients, symptoms may be difficult to attribute to myocardial ischemia; thus, the indications used in this table provide only anatomic and noninvasive test findings for review. Note that for patients being evaluated before a percutaneous valve procedure, the option for CABG surgery is blocked out, as it is assumed such patients have clinical factors making their risk of surgery prohibitively high.

\section{DISCUSSION}

The AUC are intended to inform clinicians, patients, and health policy makers about the reasonable use of technologies to help improve patient symptoms and health outcomes. Since 2005, the American College of Cardiology, along with its professional partners, has worked to provide criteria for both invasive and noninvasive testing and selected treatments, with the intention of further expanding the AUC portfolio.

The 2017 Appropriate Use Criteria for Revascularization in Patients With Stable Ischemic Heart Disease is the culmination of approximately 2 years of review and revision to the existing AUC. In response to comments from multiple stakeholders, the current AUC has several important changes. ${ }^{41}$ First, this document will use the new terms "appropriate care," "may be appropriate care," and "rarely appropriate care," which were described in the updated AUC methodology paper. ${ }^{2}$ Second, the composition of the rating panel was changed slightly to include 5 cardiac surgeons, 5 interventional cardiologists, 6 cardiologists not directly involved with performing revascularization, and 1 outcomes researcher. Third, the new criteria stratify symptoms into 2 general groups-asymptomatic and ischemic symptoms - to be inclusive of the spectrum of complaints that may occur from myocardial ischemia. Furthermore, because of the variety of symptoms that may indicate myocardial ischemia, individual patient variation in how they are described, and observer variability in the assessment of symptom severity, the writing group chose to abandon the Canadian Cardiac Society classification. However, the current criteria continue to emphasize the use of more objective measures of ischemia within indications to stratify patients into low-risk or intermediate-/high-risk findings, as described in the SIHD guideline. Fourth, the scenarios expand the use of intracoronary physiological testing, which should be 
TABLE 1.4. Left main coronary artery stenosis

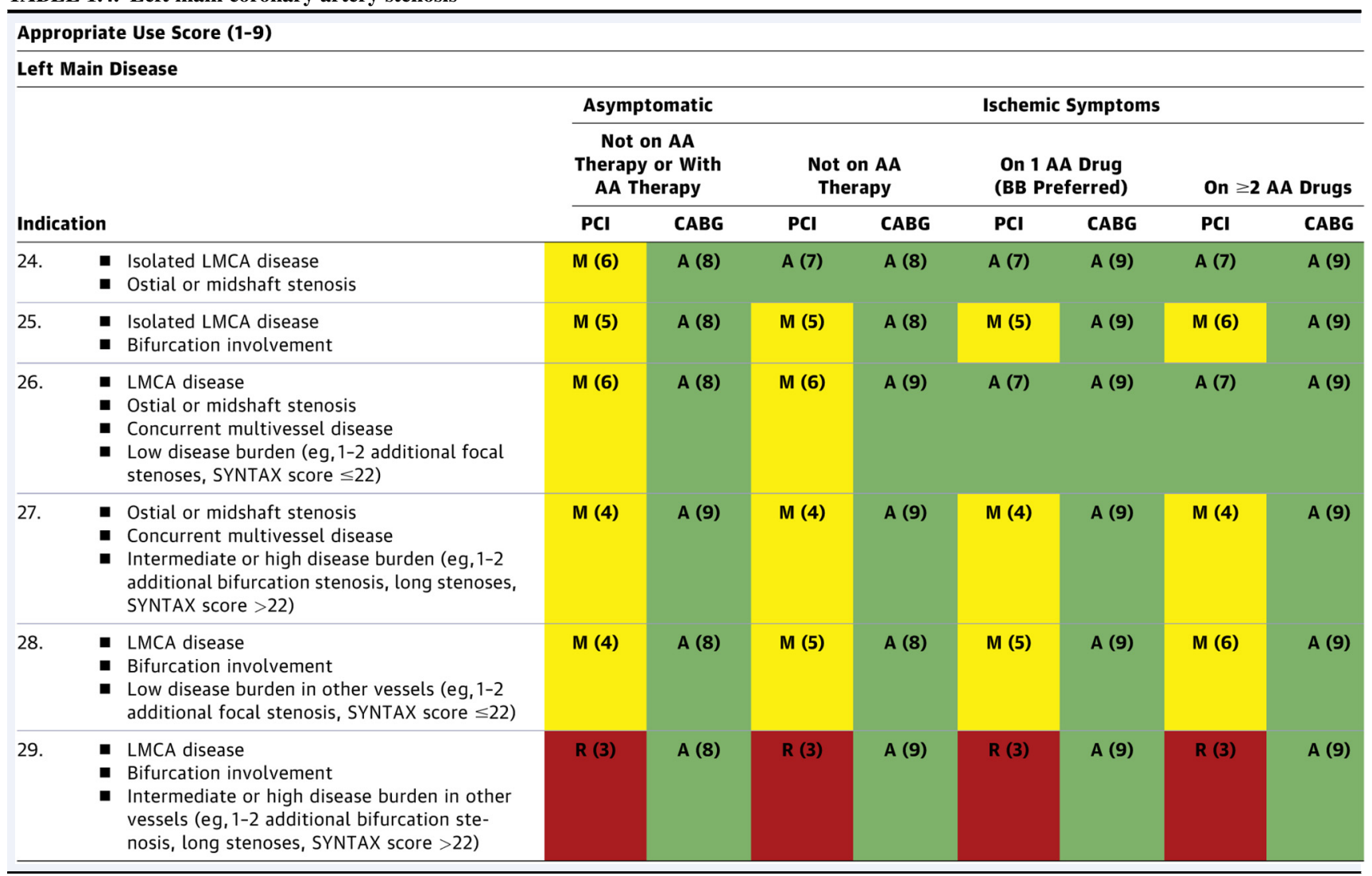

The number in parentheses next to the rating reflects the median score for that indication. $A$, Appropriate; $A A$, antianginal; $B B$, beta blockers; $C A B G$, coronary artery bypass graft; $L M C A$, left main coronary artery; $M$, may be appropriate; $P C I$, percutaneous coronary intervention; $R$, rarely appropriate; SYNTAX, Synergy between PCI with Taxus and Cardiac Surgery trial.

performed primarily with FFR as it is a well-validated measurement and is associated with clinical outcomes following PCI. Fifth, the structure of the AUC tables concerning the use of antianginal therapy has changed to reflect typical practice patterns rating patients on the basis of no antianginal therapy, use of 1 antianginal drug, or use of 2 or more antianginal drugs. As in earlier documents, it is assumed that all patients are being treated with guideline-directed medical therapies to reduce risk. Finally, in an effort to capture patients who have not previously been categorized, the current AUC also rate coronary revascularization in patients being considered for renal transplantation and percutaneous valve procedures.

Review of the ratings demonstrate some themes around revascularization of patients with SIHD that are consistent with existing clinical practice guidelines. In general, in patients with a low burden of coronary disease (eg, single-vessel disease), low-risk findings on noninvasive testing, and/or no antianginal therapy, revascularization by PCI or CABG surgery for care is felt to be rarely appropriate as the initial step. As disease burden progresses through 2-vessel to 3-vessel and left main disease, revascularization by PCI or CABG frequently becomes rated as "may be appropriate care" or "appropriate care," with CABG surgery consistently rated as "appropriate care" for intermediate or high disease complexity (SYNTAX $\geq 22$ ) even in patients with ischemic symptoms who are not on antianginal therapy. Of note, CABG surgery was consistently rated as "appropriate care" and PCI as "rarely appropriate care" for left main bifurcation disease with intermediate or high disease burden in other vessels.

Repeat CABG surgery was felt to be rarely appropriate in patients with a functional patent IMA to the LAD in all but 1 indication, with both PCI and CABG being rated as either "may be appropriate care" or "appropriate care" in the other indications, reflecting the complex and individualized decision making required in these patients. With the exception of a few specific scenarios in asymptomatic patients with a low disease burden, revascularization options were considered as "may be appropriate care" or "appropriate care" options. Although not directly rated, the use of fractional flow reserve for evaluation of renal transplant patients may be considered and will be addressed in future revascularization documents. Revascularization by PCI was considered appropriate care for the majority of 
TABLE 2.1. IMA to LAD patent and without significant stenoses

\begin{tabular}{|c|c|c|c|c|c|c|c|c|c|}
\hline \multicolumn{10}{|c|}{ Appropriate Use Score (1-9) } \\
\hline \multirow{3}{*}{\multicolumn{2}{|c|}{ Indication }} & \multirow{2}{*}{\multicolumn{2}{|c|}{$\begin{array}{c}\text { Asymptomatic } \\
\text { Not on AA } \\
\text { Therapy or With } \\
\text { AA Therapy }\end{array}$}} & \multicolumn{6}{|c|}{ Ischemic Symptoms } \\
\hline & & & & \multicolumn{2}{|c|}{$\begin{array}{c}\text { Not on AA } \\
\text { Therapy }\end{array}$} & \multicolumn{2}{|c|}{$\begin{array}{l}\text { On } 1 \text { AA Drug } \\
\text { (BB Preferred) }\end{array}$} & \multicolumn{2}{|c|}{ On $\geq 2$ AA Drugs } \\
\hline & & $\mathbf{P C I}$ & CABG & PCI & CABG & PCI & CABG & PCI & CABG \\
\hline \multicolumn{10}{|c|}{ Stenosis Supplying 1 Territory Disease (Bypass Graft or Native Artery) to Territory Other Than Anterior } \\
\hline 30. & - Low-risk findings on noninvasive testing & R (3) & $\mathbf{R}(1)$ & $\mathrm{R}(3)$ & R (2) & M (6) & $\mathrm{R}(3)$ & A (7) & M (4) \\
\hline 31. & $\begin{array}{l}\text { - Intermediate- or high-risk findings on } \\
\text { noninvasive testing }\end{array}$ & M (5) & $\mathrm{R}(3)$ & M (5) & $\mathbf{R}(3)$ & A (7) & M (4) & A (8) & M (5) \\
\hline 32. & $\begin{array}{l}\text { - No stress test performed or, if performed, the } \\
\text { results are indeterminate } \\
\text { - FFR of stenosis } \leq 0.80^{*}\end{array}$ & M (4) & R (3) & M (4) & R (3) & M (6) & M (4) & $A(8)$ & M (5) \\
\hline
\end{tabular}

Stenoses Supplying 2 Territories (Bypass Graft or Native Artery, Either 2 Separate Vessels or Sequential Graft Supplying 2 Territories) Not Including Anterior Territory

\begin{tabular}{|l|l|l|l|l|l|l|l|l|}
\hline 33. & Low-risk findings on noninvasive testing & $\mathbf{R}(3)$ & $R(2)$ & M (4) & A (3) & M (6) & R (3) \\
\hline 34. & $\begin{array}{l}\text { Intermediate- or high-risk findings on } \\
\text { noninvasive testing }\end{array}$ & M (5) & R (3) & M (5) & M (4) & A (7) & M (5) \\
\hline
\end{tabular}

The number in parentheses next to the rating reflects the median score for that indication. $A$, Appropriate; $A A$, antianginal; $B B$, beta blockers; $C A B G$, coronary artery bypass graft; $F F R$, fractional flow reserve; $I M A$, internal mammary artery; $L A D$, left anterior descending coronary artery; $M$, may be appropriate; $P C I$, percutaneous coronary intervention; $R$, rarely appropriate. ${ }^{*}$ Substitution of a newer coronary pressure ratio that does not require hyperemia for FFR may be considered provided the appropriate reference values are used.

patients being evaluated before a percutaneous valve procedure.

\section{Application of Criteria}

There are many potential applications for AUC, including their adoption by Centers for Medicare \&
Medicaid Services regulators as a means of evaluating care. Clinicians can use the ratings for decision support or as an educational tool when considering the need for revascularization. Moreover, these criteria can be used to facilitate discussions with patients and/or referring physicians about the need for revascularization. The original intent of

TABLE 2.2. IMA to LAD not patent

\begin{tabular}{|c|c|c|c|c|c|c|c|c|c|}
\hline \multicolumn{10}{|c|}{ Appropriate Use Score (1-9) } \\
\hline \multirow{3}{*}{\multicolumn{2}{|c|}{ Indication }} & \multirow{2}{*}{\multicolumn{2}{|c|}{$\begin{array}{c}\text { Asymptomatic } \\
\text { Not on AA } \\
\text { Therapy or With } \\
\text { AA Therapy }\end{array}$}} & \multicolumn{6}{|c|}{ Ischemic Symptoms } \\
\hline & & & & \multicolumn{2}{|c|}{$\begin{array}{l}\text { Not on AA } \\
\text { Therapy }\end{array}$} & \multicolumn{2}{|c|}{$\begin{array}{l}\text { On } 1 \text { AA Drug } \\
\text { (BB Preferred) }\end{array}$} & \multicolumn{2}{|c|}{ On $\geq 2$ AA Drugs } \\
\hline & & PCI & CABG & PCI & CABG & $\mathbf{P C I}$ & CABG & $\mathbf{P C I}$ & CABG \\
\hline \multicolumn{10}{|c|}{ Stenosis Supplying 1-Territory Disease (Bypass Graft or Native Artery)-Anterior (LAD) Territory } \\
\hline 35. & - Low-risk findings on noninvasive testing & M (4) & $\mathrm{R}(3)$ & M (5) & R (3) & M (6) & M (4) & $A(7)$ & M (5) \\
\hline 36. & $\begin{array}{l}\text { - Intermediate- or high-risk findings on } \\
\text { noninvasive testing }\end{array}$ & M (6) & M (4) & M (6) & M (4) & $A(7)$ & M (5) & $A(8)$ & M (6) \\
\hline 37. & $\begin{array}{l}\text { - No stress test performed or, if performed, the } \\
\text { results are indeterminate } \\
\text { - FFR of stenosis } \leq 0.80^{*}\end{array}$ & M (5) & M (4) & M (6) & M (4) & $A(7)$ & M (5) & $A(8)$ & M (6) \\
\hline \multicolumn{10}{|c|}{ Stenoses Supplying 2 Territories (Bypass Graft or Native Artery, Either 2 Separate Vessels or Sequential Graft Supplying 2 Territories) LAD Plus Other Territory } \\
\hline 38. & - Low-risk findings on noninvasive testing & M (5) & M (4) & M (6) & M (4) & A (7) & M (5) & A (7) & M (6) \\
\hline 39. & $\begin{array}{l}\text { - Intermediate- or high-risk findings on } \\
\text { noninvasive testing }\end{array}$ & M (6) & M (5) & A (7) & M (6) & A (7) & $A(7)$ & A (8) & A (8) \\
\hline \multicolumn{10}{|c|}{ Stenoses Supplying 3 Territories (Bypass Graft or Native Arteries, Separate Vessels, Sequential Grafts, or Combination Thereof) LAD Plus 2 Other Territories } \\
\hline 40. & - Low-risk findings on noninvasive testing & M (5) & M (5) & M (6) & M (5) & M (6) & M (6) & A (7) & $A(7)$ \\
\hline & $\begin{array}{l}\text { - Intermediate- or high-risk findings on } \\
\text { noninvasive testing }\end{array}$ & $A(7)$ & $A(7)$ & $A(7)$ & A (7) & $A(7)$ & $A(7)$ & A (8) & $A(8)$ \\
\hline
\end{tabular}

The number in parentheses next to the rating reflects the median score for that indication. $A$, Appropriate; $A A$, antianginal; $B B$, beta blockers; $C A B G$, coronary artery bypass graft; $F F R$, fractional flow reserve; $I M A$, internal mammary artery; $L A D$, left anterior descending coronary artery; $M$, may be appropriate; $P C I$, percutaneous coronary intervention; $R$, rarely appropriate. *Substitution of a newer physiological pressure ratio that does not require hyperemia for FFR may be considered provided the appropriate reference values are used. 
TABLE 3.1. Stable ischemic heart disease undergoing procedures for which coronary revascularization may be considered

\begin{tabular}{|c|c|c|c|c|c|c|c|c|c|}
\hline \multicolumn{10}{|c|}{ Appropriate Use Score (1-9) } \\
\hline \multirow[b]{3}{*}{ Indicat } & & \multirow{2}{*}{\multicolumn{2}{|c|}{$\begin{array}{l}\text { Asymptomatic } \\
\text { Not on AA Therapy } \\
\text { or With AA } \\
\text { Therapy }\end{array}$}} & & & \multicolumn{4}{|c|}{ Ischemic Symptoms } \\
\hline & \multirow[b]{2}{*}{ n } & & & \multicolumn{2}{|c|}{ Not on AA Therapy } & \multicolumn{2}{|c|}{$\begin{array}{l}\text { On } 1 \text { AA Drug } \\
\text { (BB Preferred) }\end{array}$} & \multicolumn{2}{|c|}{ On $\geq 2$ AA Drugs } \\
\hline & & PCI & CABG & PCI & CABG & PCI & CABG & PCI & CABG \\
\hline \multicolumn{10}{|c|}{ Patients Undergoing Renal Transplantation, No Diabetes } \\
\hline 42. & $\begin{array}{l}\text { - One- or two-vessel CAD, no proximal LAD involvement, with low-risk noninvasive } \\
\text { findings }\end{array}$ & $\mathrm{R}(3)$ & $\mathrm{R}(2)$ & M (4) & $\mathrm{R}(3)$ & M (6) & M (4) & $A(7)$ & M(5) \\
\hline 43. & $\begin{array}{l}\text { - One- or two-vessel CAD, no proximal LAD involvement, with intermediate- or high-risk } \\
\text { noninvasive findings }\end{array}$ & $M(5)$ & M(4) & M (6) & M (4) & A (7) & M (5) & A (8) & M(6) \\
\hline 44. & - One- or two-vessel $C A D$, including proximal $L A D$, with low-risk noninvasive findings & M (5) & M(4) & M (6) & M (5) & M (6) & M(6) & A (8) & $A(7)$ \\
\hline 45. & $\begin{array}{l}\text { - One- or two-vessel CAD, including proximal LAD, with intermediate- or high-risk } \\
\text { noninvasive findings }\end{array}$ & M (6) & M (6) & $A(7)$ & A (7) & $A(7)$ & $A(7)$ & A (8) & A (8) \\
\hline 46. & $\begin{array}{l}\text { - Left main and/or three-vessel disease, with intermediate- or high-risk noninvasive } \\
\text { findings (eg, SYNTAX } \leq 22 \text { ) }\end{array}$ & M (6) & $A(7)$ & $A(7)$ & $A(7)$ & $A(7)$ & $A(7)$ & A (8) & $A(8)$ \\
\hline 47. & $\begin{array}{l}\text { - Left main and/or three-vessel disease, with intermediate- or high-risk noninvasive } \\
\text { findings (eg, SYNTAX > 22) }\end{array}$ & M (5) & $A(7)$ & M (6) & A (8) & M (6) & $A(8)$ & M (6) & $A(9)$ \\
\hline \multicolumn{10}{|c|}{ Patients Undergoing Renal Transplantation, Diabetes Present } \\
\hline 48. & $\begin{array}{l}\text { - One- or two-vessel CAD, no proximal LAD involvement, with low-risk noninvasive } \\
\text { findings }\end{array}$ & $\mathrm{R}(3)$ & $\mathrm{R}(3)$ & M (4) & $\mathrm{R}(3)$ & M (5) & M (4) & A (7) & M (6) \\
\hline 49. & $\begin{array}{l}\text { - One- or two-vessel CAD, no proximal LAD involvement, with intermediate- or high-risk } \\
\text { noninvasive findings }\end{array}$ & M (5) & M (4) & M (5) & M (4) & M (6) & M (5) & A (7) & $A(7)$ \\
\hline 50. & - One- or two-vessel CAD, including proximal LAD, with low-risk noninvasive findings & M (5) & M (5) & M (5) & M (6) & M (5) & $A(7)$ & $A(7)$ & $A(7)$ \\
\hline 51. & $\begin{array}{l}\text { - One- or two-vessel CAD, including proximal LAD, with intermediate- or high-risk } \\
\text { noninvasive findings }\end{array}$ & M (6) & M (6) & M (6) & $A(7)$ & M (6) & $A(7)$ & $A(7)$ & $A(8)$ \\
\hline 52. & $\begin{array}{l}\text { - Left main and/or three-vessel disease, with intermediate- or high-risk noninvasive } \\
\text { findings (eg, SYNTAX } \leq 22 \text { ) }\end{array}$ & M (6) & A (8) & M (6) & A (8) & M (6) & A (8) & A (7) & A (9) \\
\hline 53. & $\begin{array}{l}\text { - Left main and/or three-vessel disease, with intermediate- or high-risk noninvasive } \\
\text { findings (eg, SYNTAX > 22) }\end{array}$ & M (5) & A (8) & M (5) & A (8) & M (5) & $A(9)$ & M (5) & A (9) \\
\hline \multicolumn{10}{|c|}{ Patient Who Will Undergo a Percutaneous Valve Procedure (TAVR, Mitraclip. Others) } \\
\hline 54. & $\begin{array}{l}\text { - One- or two-vessel CAD, no proximal LAD involvement, with low-risk noninvasive } \\
\text { findings }\end{array}$ & \multicolumn{2}{|c|}{ M (4) } & \multicolumn{2}{|c|}{ M (4) } & \multicolumn{2}{|c|}{ M (6) } & \multicolumn{2}{|c|}{$A(8)$} \\
\hline 55. & $\begin{array}{l}\text { - One- or two-vessel CAD, no proximal LAD involvement, with intermediate- or high-risk } \\
\text { noninvasive findings }\end{array}$ & \multicolumn{2}{|c|}{$A(7)$} & \multicolumn{2}{|c|}{$A(7)$} & \multicolumn{2}{|c|}{$A(7)$} & \multicolumn{2}{|c|}{$A(8)$} \\
\hline 56. & - One- or two-vessel CAD, including proximal LAD, with low-risk noninvasive findings & \multirow{2}{*}{\multicolumn{2}{|c|}{$\begin{array}{ll}M(6) \\
A(7)\end{array}$}} & \multicolumn{2}{|c|}{ M (6) } & \multicolumn{2}{|c|}{$A(7)$} & \multicolumn{2}{|c|}{ A (8) } \\
\hline 57. & $\begin{array}{l}\text { - One- or two-vessel CAD, including proximal LAD, with intermediate- or high-risk } \\
\text { noninvasive findings }\end{array}$ & & & \multicolumn{2}{|c|}{ A (7) } & \multicolumn{2}{|c|}{$A(8)$} & \multicolumn{2}{|c|}{$A(9)$} \\
\hline 58. & $\begin{array}{l}\text { - Left main and/or three-vessel disease, with intermediate- or high-risk noninvasive } \\
\text { findings (eg, SYNTAX } \leq 22 \text { ) }\end{array}$ & \multicolumn{2}{|c|}{ A (8) } & A $(8$ & & \multicolumn{2}{|c|}{$A(8)$} & \multicolumn{2}{|c|}{$A(9)$} \\
\hline 59. & $\begin{array}{l}\text { - Left main and//r three-vessel disease, with intermediate- or high-risk noninvasive } \\
\text { findings (eg, SYNTAX > 22) }\end{array}$ & \multicolumn{2}{|c|}{$A(7)$} & A (7) & & \multicolumn{2}{|c|}{$A(8)$} & \multicolumn{2}{|c|}{$A(8)$} \\
\hline
\end{tabular}

The number in parentheses next to the rating reflects the median score for that indication. $A$, Appropriate; $A A$, antianginal; $B B$, beta blockers; $C A B G$, coronary artery bypass graft; $C A D$, coronary artery disease; $L A D$, left anterior descending coronary artery; $M$, may be appropriate; $P C I$, percutaneous coronary intervention; $R$, rarely appropriate; SYNTAX, Synergy between PCI with Taxus and Cardiac Surgery trial; TAVR, transcatheter aortic valve replacement.

the AUC was to provide a tool to identify patterns of care, including both the overuse and underuse of various services. In fact, some of the initial publications related to AUC identified underuse and the consequences of underuse rather than overuse of services. ${ }^{42,43}$ Facilities have used these criteria to design protocols to facilitate the appropriate care of patients. Some payers have adopted the AUC for use in the preauthorization of procedures or retrospectively for quality reports. Although the AUC were never intended to determine payment in individual patients, some payers have adopted the AUC for this purpose. The desire of payers to control costs is understood, but it should be in the context of developing rational payment management strategies to ensure their members receive necessary, beneficial, and cost-effective cardiovascular care, rather than for other purposes. It is expected that services performed for "appropriate" or "may be appropriate" indications will receive reimbursement. In contrast, services performed for "rarely appropriate" indications should be justified by additional documentation to justify payment because of the unique circumstances or the clinical profile that must exist in such a patient. It is critical to emphasize that the writing group, technical panel, Appropriate Use Criteria Task Force, and clinical community do not believe a rating of "may be appropriate" is justification to deny reimbursement for revascularization. Rather, "may be appropriate" ratings are those in which the available data vary and many other factors exist that may affect the decision to perform or not perform revascularization. The opinions of the technical panel often varied for these indications, reflecting that additional research is needed.

The writing group recognizes the need to align the collection of clinical data required for the determination of appropriate use with appropriate methods to reduce the burden of data collection. To this end, the NCDR CathPCI Registry group has been engaged in a parallel process to ensure that needed data elements are incorporated into the 
Registry. The criteria will also be evaluated for collection by the Society for Thoracic Surgeons registry. Incorporating fields to identify patients who are not felt to be candidates for PCI or CABG surgery has been suggested to ensure proper mapping of the AUC in the course of medical decision making. The writing committee believes the key step to ensuring that the AUC are iterated and continually improved is the use of a feedback cycle of data between current clinical practice and the Registry. The writing group also believes that the mapping of the data elements on the NCDR CathPCI Registry data collection from the AUC should be transparent for all providers to review and implement local systems of care.

In conclusion, this document represents the current understanding of the clinical benefit of coronary revascularization with respect to health outcomes and survival. These criteria have been developed through the AUC process and alignment with the evidence and recommendations from clinical practice guidelines. This is intended to provide a practical guide to clinicians and patients when considering revascularization. As with all AUC, some of these ratings will require research and further evaluation to provide the greatest information and benefit to clinical decision making. We anticipate that the utility and ability of these criteria to improve the quality of care will be measured by the overall use and adoption of the criteria. With each update, the AUC for coronary revascularization in SIHD have become more refined and specific, while areas for continued focus and research have been identified.

\section{ACC PRESIDENT AND STAFF}

Richard A. Chazal, MD, FACC, President

Shalom Jacobovitz, Chief Executive Officer

William J. Oetgen, MD, FACC, Executive Vice President, Science, Education and Quality

Joseph M. Allen, MA, Director, Team Leader, Clinical

Policy and Pathways

Leah White, MPH, CCRP, Team Leader, Appropriate Use Criteria

Maria Velásquez, Senior Research Specialist, Appropriate Use Criteria

Amelia Scholtz, PhD, Publications Manager, Clinical Policy and Pathways

\section{References}

1. Patel MR, Dehmer GJ, Hirshfeld JW, Smith PK, Spertus JA. ACCF/SCAI/STS/ AATS/AHA/ASNC/HFSA/SCCT 2012 appropriate use criteria for coronary revascularization focused update: a report of the American College of Cardiology Foundation Appropriate Use Criteria Task Force, Society for Cardiovascular Angiography and Interventions, Society of Thoracic Surgeons, American Association for Thoracic Surgery, American Heart Association, American Society of Nuclear Cardiology, and the Society of Cardiovascular Computed Tomography. J Am Coll Cardiol. 2012;59:857-81.
2. Hendel RC, Patel MR, Allen JM, et al. Appropriate use of cardiovascular technology: 2013 ACCF appropriate use criteria methodology update: a report of the American College of Cardiology Foundation Appropriate Use Criteria Task Force. J Am Coll Cardiol. 2013;61:1305-17.

3. Fihn SD, Gardin JM, Abrams J, et al. 2012 ACCF/AHA/ACP/AATS/PCNA/ SCAI/STS guideline for the diagnosis and management of patients with stable ischemic heart disease: a report of the American College of Cardiology Foundation/American Heart Association Task Force on Practice Guidelines, and the American College of Physicians, American Association for Thoracic Surgery, Preventive Cardiovascular Nurses Association, Society for Cardiovascular Angiography and Interventions, and Society of Thoracic Surgeons. J Am Coll Cardiol. 2012;60:e44-164.

4. Fihn SD, Blankenship JC, Alexander KP, et al. 2014 ACC/AHA/AATS/ PCNA/SCAI/STS focused update of the guideline for the diagnosis and management of patients with stable ischemic heart disease: a report of the American College of Cardiology/American Heart Association Task Force on Practice Guidelines, and the American Association for Thoracic Surgery, Preventive Cardiovascular Nurses Association, Society for Cardiovascular Angiography and Interventions, and Society of Thoracic Surgeons. J Am Coll Cardiol. 2014;64:1929-49.

5. De Bruyne B, Fearon WF, Pijls NH, et al. Fractional flow reserve-guided PCI for stable coronary artery disease. N Engl J Med. 2014;371:1208-17.

6. Hannan EL, Zhong Y, Walford G, et al. Coronary artery bypass graft surgery versus drug-eluting stents for patients with isolated proximal left anterior descending disease. J Am Coll Cardiol. 2014;64:2717-26.

7. Hlatky MA, Boothroyd DB, Baker LC, Go AS. Impact of drug-eluting stents on the comparative effectiveness of coronary artery bypass surgery and percutaneous coronary intervention. Am Heart J. 2015;169:149-54.

8. Windecker S, Stortecky S, Stefanini GG, et al. Revascularisation versus medical treatment in patients with stable coronary artery disease: network meta-analysis. BMJ. 2014;348:g3859.

9. Barbash IM, Dvir D, Torguson R, et al. Prognostic implications of percutaneous coronary interventions performed according to the appropriate use criteria for coronary revascularization. Cardiovasc Revasc Med. 2013;14: 316-20.

10. Bradley SM, Spertus JA, Kennedy KF, et al. Patient selection for diagnostic coronary angiography and hospital-level percutaneous coronary intervention appropriateness: insights from the National Cardiovascular Data Registry. JAMA Intern Med. 2014;174:1630-9.

11. Chan PS, Rao SV, Bhatt DL, et al. Patient and hospital characteristics associated with inappropriate percutaneous coronary interventions. J Am Coll Cardiol. 2013;62:2274-81.

12. Desai NR, Bradley SM, Parzynski CS, et al. Appropriate use criteria for coronary revascularization and trends in utilization, patient selection, and appropriateness of percutaneous coronary intervention. JAMA. 2015;314: 2045-53.

13. Ko DT, Guo H, Wijeysundera HC, et al. Assessing the association of appropriateness of coronary revascularization and clinical outcomes for patients with stable coronary artery disease. J Am Coll Cardiol. 2012;60: 1876-84.

14. Jacobs AK, Kushner FG, Ettinger SM, et al. ACCF/AHA clinical practice guide line methodology summit report: a report of the American College of Cardiology Foundation/American Heart Association Task Force on Practice Guidelines. J Am Coll Cardiol. 2013;61:213-65.

15. Hillis LD, Smith P, Anderson J, et al. 2011 ACCF/AHA guidelines for coronary artery bypass graft surgery: a report of the American College of Cardiology Foundation/American Heart Association Task Force on Practice Guidelines. J Am Coll Cardiol. 2011;58:e123-210.

16. Levine GN, O'Gara PT, Bates ER, et al. 2015 ACC/AHA/SCAI focused update on primary percutaneous coronary intervention for patients with ST-elevation myocardial infarction: an update of the 2011 ACCF/AHA/ SCAI Guideline for Percutaneous Coronary Intervention and the 2013 ACCF/AHA Guideline for the Management of ST-Elevation Myocardial Infarction: a report of the American College of Cardiology/American Heart Association Task Force on Clinical Practice Guidelines and the Society for Cardiovascular Angiography and Interventions. J Am Coll Cardiol. 2016;67:1235-50.

17. Adult Treatment Panel III. Third Report of the National Cholesterol Education Program (NCEP) Expert Panel on Detection, Evaluation, and Treatment of High Blood Cholesterol in Adults (Adult Treatment Panel III) Final Report. Circulation. 2002;106:3143-421. 
18. Chobanian AV, Bakris GL, Black HR, et al. Seventh report of the Joint National Committee on Prevention, Detection, Evaluation, and Treatment of High Blood Pressure. Hypertension. 2003;42:1206-52.

19. Smith SC Jr, Benjamin EJ, Bonow RO, et al. AHA/ACCF secondary prevention and risk reduction therapy for patients with coronary and other atherosclerotic vascular disease: 2011 update: a guideline from the American Heart Association and American College of Cardiology Foundation. J Am Coll Cardiol. 2011;58: 2432-46.

20. Harold JG, Bass TA, Bashore TM, et al. ACCF/AHA/SCAI 2013 update of the clinical competence statement on coronary artery interventional procedures: a report of the American College of Cardiology Foundation/American Heart Association/American College of Physicians Task Force on Clinical Competence and Training (Writing Committee to Revise the 2007 Clinical Competence Statement on Cardiac Interventional Procedures). J Am Coll Cardiol. 2013;62:357-96.

21. Levine GN, Bates ER, Blankenship JC, et al. 2011 ACCF/AHA/SCAI guideline for percutaneous coronary intervention: a report of the American College of Cardiology Foundation/American Heart Association Task Force on Practice Guidelines and the Society for Cardiovascular Angiography and Interventions. J Am Coll Cardiol. 2011;58:e44-122.

22. Nam CW, Mangiacapra F, Entjes R, et al. Functional SYNTAX score for risk assessment in multivessel coronary artery disease. J Am Coll Cardiol. 2011;58: 1211-8.

23. Toth G, De BB, Casselman F, et al. Fractional flow reserve-guided versus angiography-guided coronary artery bypass graft surgery. Circulation. 2013; 128:1405-11.

24. Shafiq A, Arnold SV, Gosch K, et al. Patient and physician discordance in reporting symptoms of angina among stable coronary artery disease patients: insights from the Angina Prevalence and Provider Evaluation of Angina Relief (APPEAR) study. Am Heart J. 2016;175:94-100.

25. Arnold SV, Grodzinsky A, Gosch KL, et al. Predictors of physician underrecognition of angina in outpatients with stable coronary artery disease. Circ Cardiovasc Qual Outcomes. 2016;9:554-9.

26. Chewning B, Bylund CL, Shah B, Arora NK, Gueguen JA, Makoul G. Patient preferences for shared decisions: a systematic review. Patient Educ Couns. 2012;86:9-18.

27. Lin GA, Fagerlin A. Shared decision making: state of the science. Circ Cardiovasc Qual Outcomes. 2014;7:328-34.

28. Ting HH, Brito JP, Montori VM. Shared decision making: science and action. Circ Cardiovasc Qual Outcomes. 2014;7:323-7.

29. Buchanan A. Medical paternalism. Philos Public Aff. 1978;7:370-90.

30. Stacey D, Bennett CL, Barry MJ, et al. Decision aids for people facing health treatment or screening decisions. Cochrane Database Syst Rev. 2011: CD001431.
31. Coley C, Barry M, Mulley A. Screening for prostate cancer. Ann Intern Med. 1977;126:480-4.

32. von Eschenbach A, Ho R, Murphy G, et al. American Cancer Society guideline for the early detection of prostate cancer: update 1997. CA Cancer Journal Clin 1997;261-4.

33. Mulley AG Jr, Eagle KA. What is inappropriate care? JAMA. 1988;260: $540-1$.

34. Whitney SN, McGuire AL, McCullough LB. A typology of shared decision making, informed consent, and simple consent. Ann Intern Med. 2004;140: 54-9.

35. Serruys PW, Morice MC, Kappetein AP, et al. Percutaneous coronary interven tion versus coronary-artery bypass grafting for severe coronary artery disease. N Engl J Med. 2009;360:961-72.

36. de la Torre Hernandez JM, Hernandez HF, Alfonso F, et al. Prospective application of pre-defined intravascular ultrasound criteria for assessment of intermediate left main coronary artery lesions results from the multicenter LITRO study. J Am Coll Cardiol. 2011:58:351-8.

37. Kern MJ, Samady H. Current concepts of integrated coronary physiology in the catheterization laboratory. J Am Coll Cardiol. 2010;55:173-85.

38. Aqel R, Zoghbi GJ, Hage F, Dell'Italia L, Iskandrian AE. Hemodynamic evaluation of coronary artery bypass graft lesions using fractional flow reserve. Catheter Cardiovasc Interv. 2008;72:479-85.

39. Barner HB, Barnett MG. Fifteen- to twenty-one-year angiographic assessment of internal thoracic artery as a bypass conduit. Ann Thorac Surg. 1994;57:1526-8.

40. Sabik JF III, Lytle BW, Blackstone EH, Houghtaling PL, Cosgrove DM. Comparison of saphenous vein and internal thoracic artery graft patency by coronary system. Ann Thorac Surg. 2005;79:544-51.

41. Marso SP, Teirstein PS, Kereiakes DJ, Moses J, Lasala J, Grantham JA. Percutaneous coronary intervention use in the United States: defining measures of appropriateness. J Am Coll Cardiol Intv. 2012;5:229-35.

42. Hemingway H, Crook AM, Feder G, et al. Underuse of coronary revascularization procedures in patients considered appropriate candidates for revascularization. N Engl J Med. 2001;344:645-54.

43. Laouri M, Kravitz RL, French WJ, et al. Underuse of coronary revascularization procedures: application of a clinical method. J Am Coll Cardiol. 1997; 29:891-7.

Key Words: ACC appropriate use criteria, coronary artery bypass graft, coronary revascularization, percutaneous coronary intervention, stable ischemic heart disease 
APPENDIX A. ACC/AATS/AHA/ASE/ASNC/SCAI/ SCCT/STS 2017 APPROPRIATE USE CRITERIA FOR CORONARY REVASCULARIZATION IN PATIENTS WITH STABLE ISCHEMIC HEART DISEASE: PARTICIPANTS

Writing Group

Manesh R. Patel, MD, FACC, FAHA, FSCAI-Associate Professor of Medicine Director of Interventional Cardiology and Catheterization Labs, Duke University Health System, Duke Clinical Research Institute, Durham, $\mathrm{NC}$

John H. Calhoon, MD—Professor and Chair, President's Council Chair for Excellence in Surgery, Department of Cardiothoracic Surgery; Director, University of Texas Health Science Center at San Antonio, Heart and Vascular Institute, San Antonio, TX

Gregory J. Dehmer, MD, MACC, MSCAI, FAHAClinical Professor of Medicine, Texas A\&M Health Science Center College of Medicine; Vice-President and Medical Director, Cardiovascular Services, Central Texas Division, Baylor Scott \& White-Temple Memorial, Temple, TX

James Aaron Grantham, MD, FACC - Associate Clinical Professor, University of Missouri-Kansas City School of Medicine; Director, Cardiovascular Disease Fellowship Program, University of Missouri-Kansas City School of Medicine; Director, Cardiovascular Medical Education, Saint Luke's Hospital, Kansas City, MO

Thomas M. Maddox, MD, MSc, FACC, FAHANational Director, VA CART Program Cardiology, VA Eastern Colorado Health Care System; Associate Professor, Department of Medicine, Cardiology, University of Colorado, Colorado Cardiovascular Outcomes Research Consortium, Denver, CO

David J. Maron, MD, FACC, FAHA—Clinical Professor of Medicine, Cardiovascular; Director, Preventive Cardiology, Stanford University School of Medicine, Stanford, CA

Peter K. Smith, MD, FACC - Professor of Surgery, Division Chief, Cardiovascular and Thoracic Surgery, Duke University, Durham, NC

\section{Rating Panel}

Manesh R. Patel, MD, FACC, FAHA, FSCAI, Writing Committee Liaison-Associate Professor of Medicine, Director Interventional Cardiology and Catheterization Labs, Duke University Health System, Duke Clinical Research Institute, Durham, NC

Michael J. Wolk, MD, MACC, Moderator-Past President, American College of Cardiology; Clinical Professor of Medicine, Weill Medical College of Cornell University, New York Cardiology Associates, New York, NY Gregory J. Dehmer, MD, MACC, MSCAI, FAHA, Writing Committee Liaison-Clinical Professor of
Medicine, Texas A\&M Health Science Center College of Medicine; Vice-President and Medical Director, Cardiovascular Services, Central Texas Division, Baylor Scott \& White-Temple Memorial, Temple, TX

Peter K. Smith, MD, FACC, Writing Committee Liaison-Professor of Surgery, Division Chief, Cardiovascular and Thoracic Surgery, Duke University, Durham, NC

James C. Blankenship, MD, MACC, FSCAI—Staff Physician, Director, Cardiac Catheterization Laboratory, Division of Cardiology, Geisinger Medical Center, Danville, PA

Alfred A. Bove, MD, PhD, MACC-Past President, American College of Cardiology; Professor Emeritus, Lewis Katz School of Medicine, Heart and Vascular, Temple University, Philadelphia, PA

Steven M. Bradley, MD—Staff Cardiologist, VA Eastern Colorado Health Care System; Assistant Professor of Medicine, Division of Cardiology at the University of Colorado, Denver, CO

Larry S. Dean, MD, FACC, FSCAI-Professor of Medicine and Surgery, University of Washington School of Medicine; Director, University of Washington, Medicine Regional Heart Center, Seattle, WA

Peter L. Duffy, MD, FACC, FSCAI—Director of Quality for the Cardiovascular Service Line, First Health of the Carolinas, Reid Heart Institute/Moore Regional Hospital, Pinehurst North Carolina

T. Bruce Ferguson, Jr., MD, FACC-Professor of Thoracic Surgery, Department of Cardiovascular Sciences, Cardiothoracic Surgery, East Carolina Heart Institute, East Carolina University, Greenville, NC

Frederick L. Grover, MD, FACC-Professor of Cardiothoracic Surgery, Department of Cardiothoracic Surgery, University of Colorado, Denver, CO

Robert A. Guyton, MD, FACC-Chief of Cardiothoracic Surgery, Professor of Surgery, Division of Cardiothoracic Surgery, Department of Surgery; Director, Thoracic Surgery Residency Program, Emory University School of Medicine, Atlanta, GA

Mark A. Hlatky, MD, FACC-Professor of Heath Research and Policy, Health Services Research; Professor of Medicine, Cardiovascular Medicine, Stanford University School of Medicine, Stanford, CA

Harold L. Lazar, MD, FACC-Director, Cardiothoracic Research Program; Professor of Cardiothoracic Surgery, Boston University School of Medicine, Boston, MA

Vera H. Rigolin, MD, FACC-Professor, Cardiology, Northwestern University Feinberg School of Medicine, Chicago, IL

Geoffrey A. Rose, MD, FACC, FASE-Chief, Division of Cardiology, Sanger Heart and Vascular Institute, Charlotte, NC 
Richard J. Shemin, MD, FACC-Robert and Kelly Day Professor, Chief of Cardiothoracic Surgery, Executive Vice Chair of Surgery, Co-Director of the Cardiovascular Center, Director of Cardiac Quality at the Ronald Reagan UCLA Medical Center, Los Angeles, CA

Jacqueline E. Tamis-Holland, MD, FACC—Director, Interventional Cardiology Fellowship, Mount Sinai; Saint Luke's Hospital Director, Women's Heart NY Assistant Professor of Medicine, Icahn School of Medicine at Mount Sinai Hospital, New York, NY

Carl L. Tommaso, MD, FACC, FSCAI-Director, Cardiac Catheterization Laboratory, Skokie Illinois Hospital, part of the Northshore University Health System; Associate Professor of Medicine, Rush Medical College, Chicago, IL

L. Samuel Wann, MD, MACC-Past President, American College of Cardiology; Clinical Cardiologist, Columbia St. Mary's Healthcare; Medical Director, Heart Failure Program, Milwaukee, WI

John B. Wong, MD-Chief, Division of Clinical Decision Making, Primary Care Physician, Principal Investigator, Institute for Clinical Research and Health Policy Studies; Professor, Tufts University School of Medicine, Boston, MA

\section{Reviewers}

Jeffrey L. Anderson, MD, FACC-Associate Chief of Cardiology, Intermountain Medical Center, Murray, UT

James C. Blankenship, MD, MACC, MSCAI-Staff Physician, Director, Cardiac Catheterization Laboratory, Geisinger Medical Center, Division of Cardiology, Danville, PA

Jeffrey A. Brinker, MD, FACC—Professor of Medicine, Johns Hopkins Hospital, Baltimore, MD

Alexandru I. Costea, MD-Associate Professor, University of Cincinnati Medical Center, Cincinnati, $\mathrm{OH}$

Ali E. Denktas, MD, FACC—Assistant Professor, Baylor College of Medicine, Houston, TX

Lloyd W. Klein, MD, FACC-Professor of Medicine, Melrose Park, IL

Frederick G. Kushner, MD, FACC-Clinical Professor, Tulane University Medical Center; Medical Director, Heart Clinic of Louisiana, Marrero, LA

Glenn N. Levine, MD, FACC-Professor, Baylor College of Medicine, Cardiology, Pearland, TX

David Joel Maron, MD, FACC-Professor of Medicine and Emergency Medicine, Stanford University School of Medicine, Stanford, CA

James B. McClurken, MD, FACC-Director of Thoracic Surgery, Professor of Surgery Emeritus, Temple University, School of Medicine, Richard A Reif Heart Institute, Doylestown Hospital, Doylestown, PA

Robert N. Piana, MD, FACC-Professor of Medicine, Cardiology, Vanderbilt University Medical Center, Nashville, TN
John A. Spertus, M.D, MPH, FACC-Adjunct Professor of Medicine, Washington University School of Medicine, Saint Louis, MO

Raymond F. Stainback, MD, FACC—- Medical Director, Non-Invasive Cardiology Texas Heart Institute at Baylor St. Luke's Medical Center, Houston, TX

Robert C. Stoler, MD, FACC-Director of Cardiac Catheterization Laboratory, Cardiology Consultants of Texas, Dallas, TX

Todd C. Villines, MD, FACC-Co-Director of Cardiovascular Computed Tomography and Assistant Chief, Cardiology Service at Walter Reed Army Medical Center, Rockville, MD

David H. Wiener, MD, FACC-Professor of Medicine, Jefferson Medical College, Jefferson Heart Institute, Philadelphia, PA

\section{ACC Appropriate Use Criteria Task Force}

Steven R. Bailey, MD, FACC, FSCAI, FAHA-Chair, Division of Cardiology; Professor of Medicine and Radiology, Janey Briscoe Distinguished Chair, University of Texas Health Sciences Center, San Antonio, TX

Nicole Bhave, MD, FACC-Clinical Assistant Professor, Department of Internal Medicine, Division of Cardiovascular Medicine, University of Michigan Cardiovascular Center, Ann Arbor, MI

Alan S. Brown, MD, FACC—Medical Director, Midwest Heart Disease Prevention Center, Advocate Lutheran General Hospital; Director, Division of Cardiology, Park Ridge, IL

Stacie L. Daugherty, MD, FACC-Associate Professor, Division of Cardiology, Department of Medicine, University of Colorado School of Medicine, Denver, CO

Gregory J. Dehmer, MD, MACC, MSCAI, FAHACo-Chair, AUC Task Force, Clinical Professor of Medicine, Texas A\&M Health Science Center College of Medicine; Vice President and Medical Director, Cardiovascular Services, Central Texas Division, Baylor Scott and White-Temple Memorial, Temple, TX

Milind Y. Desai, MBBS, FACC-Associate Director, Clinical Investigations Heart and Vascular Institute, Cleveland Clinic, Cleveland, $\mathrm{OH}$

John U. Doherty, MD, FACC, FAHA-Co-Chair, AUC Task Force, Professor of Medicine, Jefferson Medical College of Thomas Jefferson University, Philadelphia, PA

Claire Duvernoy, MD, FACC-Cardiology Section Chief, Division of Cardiology, University of Michigan Health System, Ann Arbor, MI

Linda D. Gillam, MD, FACC-Chair, Department of Cardiovascular Medicine, Morristown Medical Center, Morristown, NJ

Robert C. Hendel, MD, FACC, FAHA, FASNCDirector of Cardiac Imaging and Outpatient Services, 
Division of Cardiology, Miami University School of Medicine, Miami, FL

Christopher M. Kramer, MD, FACC, FAHA-Former Co-Chair, AUC Task Force, Ruth C. Heede Professor of Cardiology \& Radiology; Director, Cardiovascular Imaging Center, University of Virginia Health System, Charlottesville, VA

Bruce D. Lindsay, MD, FACC_-Professor of Cardiology, Cleveland Clinic Foundation of Cardiovascular Medicine, Cleveland, $\mathrm{OH}$

Warren J. Manning, MD, FACC—Professor of Medicine and Radiology, Beth Israel Deaconess Medical Center, Division of Cardiology, Boston, MA

Manesh R. Patel, MD, FACC—Former Chair, AUC Task Force; Assistant Professor of Medicine, Division of Cardiology, Duke University Medical Center, Durham, NC

Ritu Sachdeva, MD, FACC-Associate Professor, Division of Pediatric Cardiology, Department of Pediatrics, Emory University School of Medicine, Children's Health Care of Atlanta, Sibley Heart Center Cardiology, Atlanta, GA

L. Samuel Wann, MD, MACC-Staff Cardiologist, Columbia St. Mary's Healthcare, Milwaukee, WI
David E. Winchester, MD, FACC-Assistant Professor of Medicine, University of Florida, Division of Cardiology, Gainesville, FL

Joseph M. Allen, MA-Team Leader, Clinical Policy and Pathways, American College of Cardiology, Washington, DC

\section{APPENDIX B. RELATIONSHIPS WITH INDUSTRY AND OTHER ENTITIES}

The College and its partnering organizations rigorously avoid any actual, perceived, or potential conflicts of interest that might arise as a result of an outside relationship or personal interest of a member of the rating panel. Specifically, all panelists are asked to provide disclosure statements of all relationships that might be perceived as real or potential conflicts of interest. These statements were reviewed by the Appropriate Use Criteria Task Force, discussed with all members of the rating panel at the faceto-face meeting, and updated and reviewed as necessary. The following is a table of relevant disclosures by the rating panel and oversight working group members. In addition, to ensure complete transparency, a full list of disclosure information-including relationships not pertinent to this document-is available in the Online Appendix. 


\begin{tabular}{|c|c|c|c|c|c|c|c|}
\hline Participant & Employment & Consultant & $\begin{array}{c}\text { Speakers } \\
\text { bureau }\end{array}$ & $\begin{array}{c}\text { Ownership/ } \\
\text { partnership/ } \\
\text { principal }\end{array}$ & $\begin{array}{l}\text { Personal } \\
\text { research }\end{array}$ & $\begin{array}{l}\text { Institutional, } \\
\text { organizational, } \\
\text { or other } \\
\text { financial } \\
\text { benefit }\end{array}$ & $\begin{array}{l}\text { Expert } \\
\text { witness }\end{array}$ \\
\hline $\begin{array}{l}\text { Manesh R. } \\
\text { Patel (Chair) }\end{array}$ & $\begin{array}{l}\text { Duke University Health } \\
\text { System, Duke } \\
\text { Clinical Research } \\
\text { Institute-Associate } \\
\text { Professor of } \\
\text { Medicine, Director, } \\
\text { Interventional } \\
\text { Cardiology and } \\
\text { Catheterization Labs }\end{array}$ & None & None & None & None & None & None \\
\hline $\begin{array}{l}\text { John H. } \\
\text { Calhoon }\end{array}$ & $\begin{array}{l}\text { University of Texas } \\
\text { Health Science } \\
\text { Center at San } \\
\text { Antonio, Department } \\
\text { of Cardiothoracic } \\
\text { Surgery, Heart and } \\
\text { Vascular Institute- } \\
\text { Director, Professor, } \\
\text { and Chair, Presidents } \\
\text { Council Chair for } \\
\text { Excellence in Surgery }\end{array}$ & None & None & None & None & None & None \\
\hline $\begin{array}{r}\text { Gregory J. } \\
\text { Dehmer }\end{array}$ & $\begin{array}{l}\text { Baylor Scott \& White- } \\
\text { Temple Memorial, } \\
\text { Texas A\&M Health } \\
\text { Science Center } \\
\text { College of Medicine, } \\
\text { Central Texas } \\
\text { Division-Clinical } \\
\text { Professor of Medicine, } \\
\text { Medical Director, } \\
\text { Cardiovascular } \\
\text { Services, Director, } \\
\text { Cardiology Division }\end{array}$ & None & None & None & None & None & None \\
\hline $\begin{array}{c}\text { James Aaron } \\
\text { Grantham }\end{array}$ & $\begin{array}{l}\text { Saint Luke's } \\
\text { Hospital-Associate } \\
\text { Clinical Professor, } \\
\text { University of } \\
\text { Missouri-Kansas } \\
\text { City School of } \\
\text { Medicine-Director, } \\
\text { Cardiovascular } \\
\text { Disease Fellowship } \\
\text { Program, Director, } \\
\text { Cardiovascular } \\
\text { Medical Education }\end{array}$ & $\begin{array}{l}\text { - Abbott Vascular* } \\
\text { - Asahi-Intecc* } \\
\text { - Boston Scientific* } \\
\text { - Bridgepoint } \\
\text { Medical Systems* } \\
\text { - Medtronic* }\end{array}$ & None & None & $\begin{array}{l}\text { - Abbott } \\
\text { Vascular* } \\
\text { - Asahi-Intecc* } \\
\text { - Boston } \\
\text { Scientific* } \\
\text { - Bridgepoint } \\
\text { Medical } \\
\text { Systems* } \\
\text { - Medtronic* }\end{array}$ & None & None \\
\hline $\begin{array}{c}\text { Thomas M. } \\
\text { Maddox }\end{array}$ & $\begin{array}{l}\text { VA Eastern Colorado } \\
\text { Health Care } \\
\text { System-National } \\
\text { Director, Associate }\end{array}$ & None & None & None & None & None & None \\
\hline
\end{tabular}




\begin{tabular}{|c|c|c|c|c|c|c|c|}
\hline Participant & Employment & Consultant & $\begin{array}{c}\text { Speakers } \\
\text { bureau }\end{array}$ & $\begin{array}{c}\text { Ownership/ } \\
\text { partnership/ } \\
\text { principal }\end{array}$ & $\begin{array}{l}\text { Personal } \\
\text { research }\end{array}$ & $\begin{array}{c}\text { Institutional, } \\
\text { organizational, } \\
\text { or other } \\
\text { financial } \\
\text { benefit }\end{array}$ & $\begin{array}{l}\text { Expert } \\
\text { witness }\end{array}$ \\
\hline & $\begin{array}{l}\text { Professor, } \\
\text { Department of } \\
\text { Medicine, } \\
\text { Cardiology, } \\
\text { University of } \\
\text { Colorado, Colorado } \\
\text { Cardiovascular } \\
\text { Outcomes Research } \\
\text { Consortium }\end{array}$ & & & & & & \\
\hline David J. Maron & $\begin{array}{l}\text { Stanford University } \\
\text { School of Medicine- } \\
\text { Clinical Professor of } \\
\text { Medicine, } \\
\text { Cardiovascular, } \\
\text { Director, Preventive } \\
\text { Cardiology }\end{array}$ & None & None & None & None & None & None \\
\hline Peter K. Smith & $\begin{array}{l}\text { Cardiovascular and } \\
\text { Thoracic Surgery, } \\
\text { Duke University- } \\
\text { Professor of Surgery, } \\
\text { Division Chief }\end{array}$ & None & None & None & None & None & None \\
\hline \multicolumn{8}{|l|}{ Rating Panel } \\
\hline $\begin{array}{l}\text { James C. } \\
\text { Blankenship }\end{array}$ & $\begin{array}{l}\text { Geisinger Medical } \\
\text { Center, Division of } \\
\text { Cardiology-Staff } \\
\text { Physician, Director, } \\
\text { Cardiac } \\
\text { Catheterization } \\
\text { Laboratory }\end{array}$ & None & None & None & $\begin{array}{l}\text { - Abbott } \\
\text { Vascular } \dagger \\
\text { - AstraZeneca } \dagger \\
\text { - Boston } \\
\text { Scientific } \dagger \\
\text { - GlaxoSmithKline } \dagger \\
\text { - Hamilton Health } \\
\text { Services } \dagger \\
\text { - } \text { Medinal LTD* } \\
\text { - } \text { Orexigen } \\
\text { Therapeutics/ } \\
\text { Takeda } \dagger \\
\text { - Stentys, Inc. } \dagger \\
\text { - Takeda } \\
\text { Pharmaceuticals }\end{array}$ & None & None \\
\hline $\begin{array}{c}\text { Alfred A. } \\
\text { Bove }\end{array}$ & $\begin{array}{l}\text { Temple University, } \\
\text { Lewis Katz School of } \\
\text { Medicine, Heart and } \\
\text { Vascular-Professor } \\
\text { Emeritus }\end{array}$ & None & None & None & $\begin{array}{l}\text { Merck } \\
\text { Schering- } \\
\text { Plough } \dagger\end{array}$ & None & None \\
\hline $\begin{array}{l}\text { Steven M. } \\
\text { Bradley }\end{array}$ & $\begin{array}{l}\text { VA Eastern Colorado } \\
\text { Health Care System, } \\
\text { Division of } \\
\text { Cardiology at the } \\
\text { University of } \\
\text { Colorado-Staff }\end{array}$ & None & None & None & None & None & None \\
\hline
\end{tabular}




\begin{tabular}{|c|c|c|c|c|c|c|c|}
\hline Participant & Employment & Consultant & $\begin{array}{l}\text { Speakers } \\
\text { bureau }\end{array}$ & $\begin{array}{l}\text { Ownership/ } \\
\text { partnership/ } \\
\text { principal }\end{array}$ & $\begin{array}{l}\text { Personal } \\
\text { research }\end{array}$ & $\begin{array}{c}\text { Institutional, } \\
\text { organizational, } \\
\text { or other } \\
\text { financial } \\
\text { benefit }\end{array}$ & $\begin{array}{l}\text { Expert } \\
\text { witness }\end{array}$ \\
\hline & $\begin{array}{l}\text { Cardiologist, } \\
\text { Assistant Professor of } \\
\text { Medicine }\end{array}$ & & & & & & \\
\hline Larry S. Dean & $\begin{array}{l}\text { Medicine Regional } \\
\text { Heart Center } \\
\text { University of } \\
\text { Washington School of } \\
\text { Medicine_-Professor } \\
\text { of Medicine and } \\
\text { Surgery, Director }\end{array}$ & $\begin{array}{l}\text { - Philips } \\
\text { Medical* }\end{array}$ & None & None & $\begin{array}{l}\text { Edwards } \\
\text { Lifesciences* }\end{array}$ & None & None \\
\hline Peter L. Duffy & $\begin{array}{l}\text { First Health of the } \\
\text { Carolinas, Reid Heart } \\
\text { Institute/Moore } \\
\text { Regional Hospital- } \\
\text { Director of Quality } \\
\text { for the } \\
\text { Cardiovascular } \\
\text { Service Line }\end{array}$ & None & $\begin{array}{l}\text { - Volcano } \\
\text { Corp* }\end{array}$ & None & None & None & None \\
\hline $\begin{array}{l}\text { T. Bruce } \\
\text { Ferguson, Jr. }\end{array}$ & $\begin{array}{l}\text { East Carolina Heart } \\
\text { Institute, East } \\
\text { Carolina University, } \\
\text { Department of } \\
\text { Cardiovascular } \\
\text { Sciences, } \\
\text { Cardiothoracic } \\
\text { Surgery-Professor } \\
\text { of Thoracic Surgery }\end{array}$ & None & None & - $\mathrm{RFPi} \dagger$ & $\begin{array}{l}\text { Novadaq } \\
\text { Technologies* }\end{array}$ & None & None \\
\hline $\begin{array}{c}\text { Frederick L. } \\
\text { Grover }\end{array}$ & $\begin{array}{l}\text { University of } \\
\text { Colorado, } \\
\text { Department of } \\
\text { Cardiothoracic } \\
\text { Surgery_-Professor } \\
\text { of Cardiothoracic } \\
\text { Surgery }\end{array}$ & - Somalution & None & None & None & None & None \\
\hline $\begin{array}{r}\text { Robert A. } \\
\text { Guyton }\end{array}$ & $\begin{array}{l}\text { Emory University } \\
\text { School of Medicine, } \\
\text { Division of } \\
\text { Cardiothoracic } \\
\text { Surgery, Department } \\
\text { of Surgery, Thoracic } \\
\text { Surgery Residency } \\
\text { Program-Chief of } \\
\text { Cardiothoracic } \\
\text { Surgery, Professor of } \\
\text { Surgery Director }\end{array}$ & - Medtronic* & None & None & None & None & None \\
\hline $\begin{array}{l}\text { Mark A. } \\
\text { Hlatky }\end{array}$ & $\begin{array}{l}\text { Stanford University } \\
\text { School of Medicine, } \\
\text { Cardiovascular } \\
\text { Medicine, Health }\end{array}$ & None & None & None & None & - Sanofi-Aventis & None \\
\hline
\end{tabular}




\begin{tabular}{|c|c|c|c|c|c|c|c|}
\hline Participant & Employment & Consultant & $\begin{array}{c}\text { Speakers } \\
\text { bureau }\end{array}$ & $\begin{array}{l}\text { Ownership/ } \\
\text { partnership/ } \\
\text { principal }\end{array}$ & $\begin{array}{l}\text { Personal } \\
\text { research }\end{array}$ & $\begin{array}{l}\text { Institutional, } \\
\text { organizational, } \\
\text { or other } \\
\text { financial } \\
\text { benefit }\end{array}$ & $\begin{array}{l}\text { Expert } \\
\text { witness }\end{array}$ \\
\hline & $\begin{array}{l}\text { Services Research- } \\
\text { Professor of Heath } \\
\text { Research and Policy, } \\
\text { Professor of Medicine }\end{array}$ & & & & & & \\
\hline $\begin{array}{l}\text { Harold L. } \\
\text { Lazar }\end{array}$ & $\begin{array}{l}\text { Boston University } \\
\text { School of Medicine, } \\
\text { Cardiothoracic } \\
\text { Research Program- } \\
\text { Director Professor of } \\
\text { Cardiothoracic } \\
\text { Surgery }\end{array}$ & None & None & None & None & None & None \\
\hline $\begin{array}{l}\text { Vera H. } \\
\text { Rigolin }\end{array}$ & $\begin{array}{l}\text { Northwestern } \\
\text { University Feinberg } \\
\text { School of Medicine, } \\
\text { Cardiology- } \\
\text { Professor }\end{array}$ & None & None & None & None & - Pfizer* & None \\
\hline $\begin{array}{l}\text { Geoffrey A. } \\
\text { Rose }\end{array}$ & $\begin{array}{l}\text { Division of Cardiology, } \\
\text { Sanger Heart and } \\
\text { Vascular Institute- } \\
\text { Chief }\end{array}$ & None & None & None & None & - Medtronic & None \\
\hline $\begin{array}{r}\text { Richard J. } \\
\text { Shemin }\end{array}$ & $\begin{array}{l}\text { Ronald Reagan UCLA } \\
\text { Medical Center, } \\
\text { Cardiovascular } \\
\text { Center-Director of } \\
\text { Cardiac Quality, } \\
\text { Robert and Kelly Day } \\
\text { Professor, Chief of } \\
\text { Cardiothoracic } \\
\text { Surgery, Executive } \\
\text { Vice Chair of Surgery }\end{array}$ & $\begin{array}{l}\text { - Edwards } \\
\text { Lifesciences } \\
\text { - Sorin Group }\end{array}$ & None & None & None & None & None \\
\hline $\begin{array}{l}\text { Jacqueline E. } \\
\text { Tamis-Holland }\end{array}$ & $\begin{array}{l}\text { Saint Luke's Hospital, } \\
\text { Icahn School of } \\
\text { Medicine at Mount } \\
\text { Sinai Hospital Mount } \\
\text { Sinai-Director, } \\
\text { Women's Heart NY, } \\
\text { Assistant Professor of } \\
\text { Medicine, Director, } \\
\text { Interventional } \\
\text { Cardiology } \\
\text { Fellowship }\end{array}$ & None & None & None & None & None & None \\
\hline $\begin{array}{l}\text { Carl L. } \\
\text { Tommaso }\end{array}$ & $\begin{array}{l}\text { Rush Medical College } \\
\text { in Chicago, Skokie } \\
\text { Illinois Hospital, part } \\
\text { of the Northshore } \\
\text { University Health } \\
\text { System-Director of } \\
\text { the Cardiac } \\
\text { Catheterization }\end{array}$ & None & None & None & None & None & None \\
\hline
\end{tabular}




\begin{tabular}{|c|c|c|c|c|c|c|c|}
\hline Participant & Employment & Consultant & $\begin{array}{c}\text { Speakers } \\
\text { bureau }\end{array}$ & $\begin{array}{l}\text { Ownership/ } \\
\text { partnership/ } \\
\text { principal }\end{array}$ & $\begin{array}{l}\text { Personal } \\
\text { research }\end{array}$ & $\begin{array}{l}\text { Institutional, } \\
\text { organizational, } \\
\text { or other } \\
\text { financial } \\
\text { benefit }\end{array}$ & $\begin{array}{l}\text { Expert } \\
\text { witness }\end{array}$ \\
\hline & $\begin{array}{l}\text { Laboratory, Associate } \\
\text { Professor of Medicine }\end{array}$ & & & & & & \\
\hline $\begin{array}{l}\text { L. Samuel } \\
\text { Wann }\end{array}$ & $\begin{array}{l}\text { Columbia St. Mary's } \\
\text { Healthcare-Clinical } \\
\text { Cardiologist, Medical } \\
\text { Director, Heart } \\
\text { Failure Program }\end{array}$ & $\begin{array}{l}\text { United } \\
\text { Healthcare }\end{array}$ & None & None & None & None & None \\
\hline $\begin{array}{l}\text { John B. } \\
\text { Wong }\end{array}$ & $\begin{array}{l}\text { Tufts University School } \\
\text { of Medicine-Chief, } \\
\text { Division of Clinical } \\
\text { Decision Making, } \\
\text { Primary Care } \\
\text { Physician, Principal } \\
\text { Investigator, Institute } \\
\text { for Clinical Research } \\
\text { and Health Policy } \\
\text { Studies, Professor }\end{array}$ & None & None & None & None & None & None \\
\hline \multicolumn{8}{|l|}{ Reviewers } \\
\hline $\begin{array}{l}\text { Jeffrey L. } \\
\text { Anderson }\end{array}$ & $\begin{array}{l}\text { Intermountain Medical } \\
\text { Center-Associate } \\
\text { Chief of Cardiology }\end{array}$ & $\begin{array}{l}\text { - Medicines } \\
\text { Company } \\
\text { - Sanofi-Aventis }\end{array}$ & None & None & None & None & None \\
\hline $\begin{array}{l}\text { Jeffrey A. } \\
\text { Brinker }\end{array}$ & $\begin{array}{l}\text { Johns Hopkins } \\
\text { Hospital-Professor } \\
\text { of Medicine }\end{array}$ & None & None & None & None & None & None \\
\hline $\begin{array}{l}\text { Alexandru I. } \\
\text { Costea }\end{array}$ & $\begin{array}{l}\text { University of Cincinnati } \\
\text { Medical Center- } \\
\text { Associate Professor }\end{array}$ & None & None & None & None & $\begin{array}{l}\text { - Boston } \\
\text { Scientific } \dagger\end{array}$ & None \\
\hline Ali E. Denktas & $\begin{array}{l}\text { Baylor College of } \\
\text { Medicine-Assistant } \\
\text { Professor }\end{array}$ & None & None & None & $\begin{array}{l}\text { - AstraZeneca } \\
\text { - Edwards } \\
\text { Lifesciences }\end{array}$ & None & None \\
\hline Lloyd W. Klein & $\begin{array}{l}\text { Melrose Park- } \\
\text { Professor of Medicine }\end{array}$ & None & None & None & None & None & None \\
\hline Frederick G. Kushner & $\begin{array}{l}\text { Tulane University } \\
\text { Medical Center, } \\
\text { Heart Clinic of } \\
\text { Louisiana-Clinical } \\
\text { Professor, Medical } \\
\text { Director }\end{array}$ & None & None & None & None & None & None \\
\hline Glenn N. Levine & $\begin{array}{l}\text { Baylor College of } \\
\text { Medicine, } \\
\text { Cardiology- } \\
\text { Professor }\end{array}$ & None & None & None & None & None & None \\
\hline David J. Maron & $\begin{array}{l}\text { Stanford University } \\
\text { School of Medicine- } \\
\text { Professor of Medicine } \\
\text { and Emergency } \\
\text { Medicine }\end{array}$ & None & None & None & None & None & None \\
\hline
\end{tabular}




\begin{tabular}{|c|c|c|c|c|c|c|c|}
\hline Participant & Employment & Consultant & $\begin{array}{c}\text { Speakers } \\
\text { bureau }\end{array}$ & $\begin{array}{l}\text { Ownership/ } \\
\text { partnership/ } \\
\text { principal }\end{array}$ & $\begin{array}{l}\text { Personal } \\
\text { research }\end{array}$ & $\begin{array}{l}\text { Institutional, } \\
\text { organizational, } \\
\text { or other } \\
\text { financial } \\
\text { benefit }\end{array}$ & $\begin{array}{l}\text { Expert } \\
\text { witness }\end{array}$ \\
\hline James B. McClurken & $\begin{array}{l}\text { Temple University, } \\
\text { School of Medicine, } \\
\text { Richard A Reif Heart } \\
\text { Institute, Doylestown } \\
\text { Hospital-Director of } \\
\text { Thoracic Surgery, } \\
\text { Professor of Surgery } \\
\text { Emeritus }\end{array}$ & None & None & None & None & None & None \\
\hline Robert N. Piana & $\begin{array}{l}\text { Vanderbilt University } \\
\text { Medical Center- } \\
\text { Professor of } \\
\text { Medicine, } \\
\text { Cardiology }\end{array}$ & $\begin{array}{l}\text { - Axio Research } \\
\text { - Harvard Clinical } \\
\text { Research Institute } \\
\text { - W.L. Gore \& } \\
\text { Associates, Inc. }\end{array}$ & None & None & None & None & None \\
\hline John A. Spertus & $\begin{array}{l}\text { Washington University } \\
\text { School of } \\
\text { Medicine- } \\
\text { Adjunct Professor } \\
\text { of Medicine }\end{array}$ & $\begin{array}{l}\text { - Amgen } \\
\text { - Bayer Healthcare } \\
\text { Pharmaceuticals } \\
\text { - Janssen } \\
\text { - Novartis } \\
\text { - Regeneron }\end{array}$ & None & $\begin{array}{l}\text { - Health } \\
\text { Outcomes } \\
\text { Sciences }\end{array}$ & None & None & None \\
\hline Raymond F. Stainback & $\begin{array}{l}\text { Texas Heart Institute at } \\
\text { Baylor St. Luke's } \\
\text { Medical Center, Non- } \\
\text { Invasive } \\
\text { Cardiology- } \\
\text { Medical Director }\end{array}$ & None & None & None & None & None & None \\
\hline Robert C. Stoler & $\begin{array}{l}\text { Cardiology } \\
\text { Consultants of } \\
\text { Texas-Director } \\
\text { of Cardiac } \\
\text { Catheterization } \\
\text { Laboratory }\end{array}$ & $\begin{array}{l}\text { - Boston Scientific } \\
\text { - Medtronic }\end{array}$ & None & None & None & None & None \\
\hline Todd C. Villines & $\begin{array}{l}\text { Cardiology Service at } \\
\text { Walter Reed Army } \\
\text { Medical Center- } \\
\text { Co-Director of } \\
\text { Cardiovascular } \\
\text { Computed } \\
\text { Tomography and } \\
\text { Assistant Chief }\end{array}$ & $\begin{array}{l}\text { - Boehringer } \\
\text { Ingelheim } \\
\text { Pharmaceutical* }\end{array}$ & None & None & None & None & None \\
\hline David H. Wiener & $\begin{array}{l}\text { Jefferson Medical } \\
\text { College, Jefferson } \\
\text { Heart Institute- } \\
\text { Professor of } \\
\text { Medicine }\end{array}$ & None & None & None & None & None & None \\
\hline \multicolumn{8}{|c|}{ Appropriate Use Criteria Task Force } \\
\hline Steven R. Bailey & $\begin{array}{c}\text { University of Texas } \\
\text { Health Sciences } \\
\text { Center-Chair, }\end{array}$ & None & None & None & None & None & None \\
\hline
\end{tabular}




\begin{tabular}{|c|c|c|c|c|c|c|c|}
\hline Participant & Employment & Consultant & $\begin{array}{c}\text { Speakers } \\
\text { bureau }\end{array}$ & $\begin{array}{l}\text { Ownership/ } \\
\text { partnership/ } \\
\text { principal }\end{array}$ & $\begin{array}{l}\text { Personal } \\
\text { research }\end{array}$ & $\begin{array}{l}\text { Institutional, } \\
\text { organizational, } \\
\text { or other } \\
\text { financial } \\
\text { benefit }\end{array}$ & $\begin{array}{l}\text { Expert } \\
\text { witness }\end{array}$ \\
\hline & $\begin{array}{l}\text { Division of } \\
\text { Cardiology, Professor } \\
\text { of Medicine and } \\
\text { Radiology, Janey } \\
\text { Briscoe } \\
\text { Distinguished Chair }\end{array}$ & & & & & & \\
\hline Nicole Bhave & $\begin{array}{l}\text { University of Michigan } \\
\text { Cardiovascular } \\
\text { Center, Department } \\
\text { of Internal Medicine, } \\
\text { Division of } \\
\text { Cardiovascular } \\
\text { Medicine-Clinical } \\
\text { Assistant Professor }\end{array}$ & None & None & None & None & None & None \\
\hline Alan S. Brown & $\begin{array}{l}\text { Midwest Heart Disease } \\
\text { Prevention Center, } \\
\text { Advocate Lutheran } \\
\text { General Hospital- } \\
\text { Director, Division of } \\
\text { Cardiology- } \\
\text { Medical Director }\end{array}$ & None & None & None & None & None & None \\
\hline Stacie L. Daugherty & $\begin{array}{l}\text { University of Colorado } \\
\text { School of Medicine, } \\
\text { Division of } \\
\text { Cardiology, } \\
\text { Department of } \\
\text { Medicine-Associate } \\
\text { Professor }\end{array}$ & None & None & None & None & None & None \\
\hline Gregory J. Dehmer & $\begin{array}{l}\text { Baylor Scott \& White, } \\
\text { Central Texas } \\
\text { Division, } \\
\text { Cardiovascular } \\
\text { Services Health_- } \\
\text { Medical Director }\end{array}$ & None & None & None & None & None & None \\
\hline Milind Y. Desai & $\begin{array}{l}\text { Cleveland Clinic, } \\
\text { Clinical } \\
\text { Investigations, Heart } \\
\text { and Vascular } \\
\text { Institute-Associate } \\
\text { Director }\end{array}$ & None & None & None & None & None & None \\
\hline John U. Doherty & $\begin{array}{l}\text { Thomas Jefferson } \\
\text { University, Jefferson } \\
\text { Medical College- } \\
\text { Professor of Medicine }\end{array}$ & None & None & None & None & None & None \\
\hline Claire Duvernoy & $\begin{array}{l}\text { University of Michigan } \\
\text { Health System, } \\
\text { Division of } \\
\text { Cardiology- } \\
\text { Cardiology Section } \\
\text { Chief }\end{array}$ & None & None & None & None & None & None \\
\hline
\end{tabular}




\begin{tabular}{|c|c|c|c|c|c|c|c|}
\hline Participant & Employment & Consultant & $\begin{array}{c}\text { Speakers } \\
\text { bureau }\end{array}$ & $\begin{array}{c}\text { Ownership/ } \\
\text { partnership/ } \\
\text { principal }\end{array}$ & $\begin{array}{l}\text { Personal } \\
\text { research }\end{array}$ & $\begin{array}{c}\text { Institutional, } \\
\text { organizational, } \\
\text { or other } \\
\text { financial } \\
\text { benefit }\end{array}$ & $\begin{array}{l}\text { Expert } \\
\text { witness }\end{array}$ \\
\hline Linda D. Gillam & $\begin{array}{l}\text { Morristown Medical } \\
\text { Center, Department } \\
\text { of Cardiovascular } \\
\text { Medicine-Chair }\end{array}$ & $\begin{array}{l}\text { - Edwards } \\
\text { Lifesciences* } \\
\text { - Medtronic } \dagger\end{array}$ & None & None & None & None & None \\
\hline Robert C. Hendel & $\begin{array}{l}\text { Miami University } \\
\text { School of Medicine, } \\
\text { Division of } \\
\text { Cardiology- } \\
\text { Director of Cardiac } \\
\text { Imaging and } \\
\text { Outpatient Services }\end{array}$ & None & None & None & None & None & None \\
\hline Christopher M. Kramer & $\begin{array}{l}\text { University of Virginia } \\
\text { Health System-Ruth } \\
\text { C. Heede Professor of } \\
\text { Cardiology \& } \\
\text { Radiology, Director, } \\
\text { Cardiovascular } \\
\text { Imaging Center }\end{array}$ & None & None & None & None & None & None \\
\hline Bruce D. Lindsay & $\begin{array}{l}\text { Cleveland Clinic } \\
\text { Foundation of } \\
\text { Cardiovascular } \\
\text { Medicine-Professor } \\
\text { of Cardiology }\end{array}$ & None & None & None & None & None & None \\
\hline Warren J. Manning & $\begin{array}{l}\text { Beth Israel Deaconess } \\
\text { Medical Center, } \\
\text { Division of } \\
\text { Cardiology- } \\
\text { Professor of Medicine } \\
\text { and Radiology }\end{array}$ & - Merck & None & None & $\begin{array}{l}\text { - Philips } \\
\text { Medical } \\
\text { Systems* }\end{array}$ & None & None \\
\hline Manesh R. Patel & $\begin{array}{l}\text { Duke University } \\
\text { Medical Center, } \\
\text { Division of } \\
\text { Cardiology- } \\
\text { Assistant Professor of } \\
\text { Medicine }\end{array}$ & None & None & None & None & None & None \\
\hline Ritu Sachdeva & $\begin{array}{l}\text { Emory University } \\
\text { School of Medicine, } \\
\text { Children's Health } \\
\text { Care of Atlanta, } \\
\text { Sibley Heart Center } \\
\text { Cardiology, Division } \\
\text { of Pediatric } \\
\text { Cardiology, } \\
\text { Department of } \\
\text { Pediatrics- } \\
\text { Associate Professor }\end{array}$ & None & None & None & None & None & None \\
\hline L. Samuel Wann & $\begin{array}{l}\text { Columbia St. Mary’s } \\
\text { Healthcare—Staff } \\
\text { Cardiologist }\end{array}$ & None & None & None & None & None & None \\
\hline
\end{tabular}




\begin{tabular}{|c|c|c|c|c|c|c|c|}
\hline Participant & Employment & Consultant & $\begin{array}{c}\text { Speakers } \\
\text { bureau }\end{array}$ & $\begin{array}{l}\text { Ownership/ } \\
\text { partnership/ } \\
\text { principal }\end{array}$ & $\begin{array}{l}\text { Personal } \\
\text { research }\end{array}$ & $\begin{array}{l}\text { Institutional, } \\
\text { organizational, } \\
\text { or other } \\
\text { financial } \\
\text { benefit }\end{array}$ & $\begin{array}{l}\text { Expert } \\
\text { witness }\end{array}$ \\
\hline David Winchester & $\begin{array}{l}\text { University of Florida, } \\
\text { Division of } \\
\text { Cardiology- } \\
\text { Assistant Professor of } \\
\text { Medicine }\end{array}$ & None & None & None & None & None & None \\
\hline Joseph M. Allen & $\begin{array}{l}\text { American College of } \\
\text { Cardiology-Team } \\
\text { Leader, Clinical } \\
\text { Policy and Pathways }\end{array}$ & None & None & None & None & None & None \\
\hline \multicolumn{8}{|c|}{$\begin{array}{l}\text { Note: A standard exemption to the ACC relationship with industry policy is extended to AUC writing groups, because they do not make recommendations but rather prepare } \\
\text { ackground materials and typical clinical scenarios/indications that are rated independently by a separate panel of experts. This table represents relevant relationships of } \\
\text { articipants with industry and other entities that were reported by reviewers at the time this document was under development. The table does not necessarily reflect relationships } \\
\text { vith industry at the time of publication. A person is deemed to have a significant interest in a business if the interest represents ownership of } \geq 5 \% \text { of the voting stock or share of } \\
\text { he business entity, or ownership of } \geq \$ 5,000 \text { of the fair market value of the business entity; or if funds received by the person from the business entity exceed } 5 \% \text { of the person's } \\
\text { ross income for the previous year. Relationships that exist with no financial benefit are also included for the purpose of transparency. Relationships in this table are modest unless } \\
\text { therwise noted. Please refer to http://www.acc.org/guidelines/about-guidelines-and-clinical-documents/relationships-with-industry-policy for definitions of disclosure } \\
\text { categories or additional information about the ACC Disclosure Policy for Writing Committees. ACC, American College of Cardiology; AUC, appropriate use criteria. } \\
\text { Significant relationship. †No financial benefit. }\end{array}$} \\
\hline
\end{tabular}

